\title{
ANOTAÇÕES DE JOAQUIM REIS \\ REGISTRO FOTOGRÁFICO OU REALIDADE CONSTRUÍDA?
}

DISSERTAÇÃO APRESENTADA AO PROGRAMA DE PÓS-GRADUAÇÃO EM ARTES VISUAIS DA ESCOLA DE COMUNICAÇÕES E ARTES DA UNIVERSIDADE DE SÃO PAULO, COMO EXIGÊNCIA PARCIAL PARA OBTENÇÃO DO TÍTULO DE MESTRE EM ARTES, ÁREA DE CONCENTRAÇÃO POÉTICAS VISUAIS, SOB ORIENTAÇÃO DO PROF. DR. CARLOS ALBERTO FAJARDO

PROGRAMA DE PÓS-GRADUAÇÃO EM ARTES VISUAIS

ESCOLA DE COMUNICAÇÃO E ARTES - UNIVERSIDADE DE SÃO PAULO

SÃO PAULO, 2009 


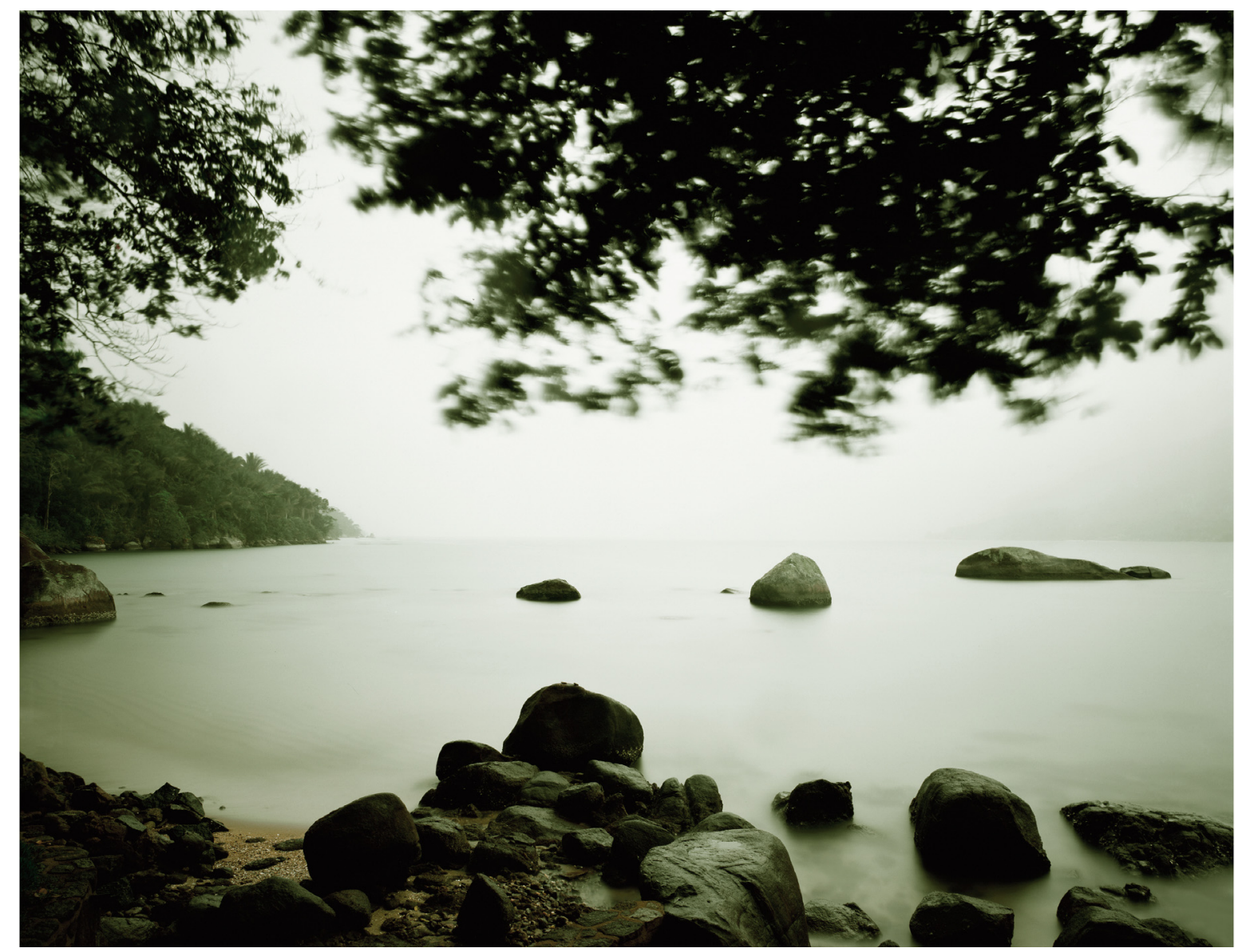



para Catarina, que nasceu durante minha pesquisa de mestrado,

Francisco e Max, meus melhores amigos,

Carla, mãe dos nossos filhos, minha companheira. 


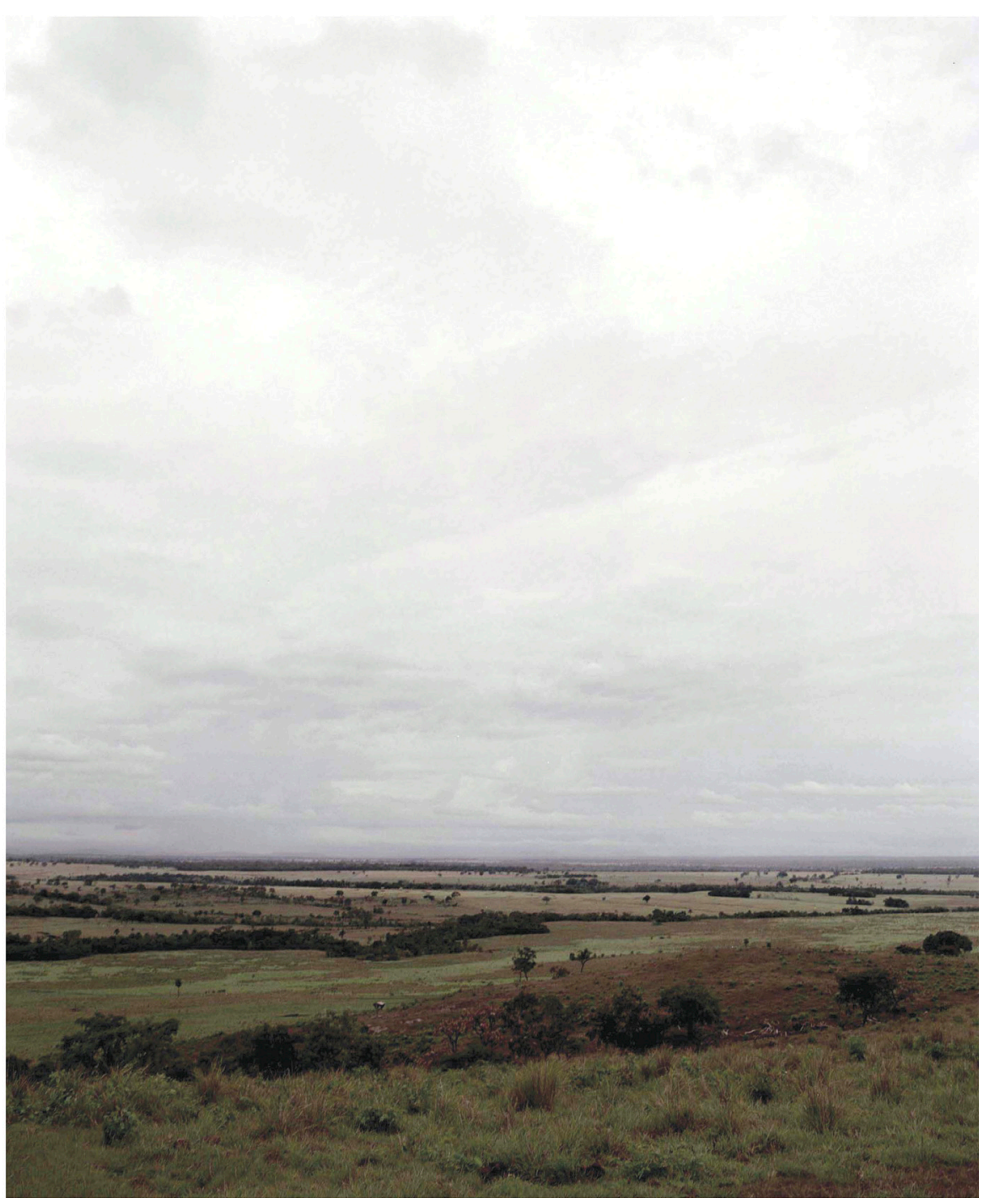




\section{AGRADECIMENTOS}

Carlos Fajardo, que orientou os caminhos da minha pesquisa ajundando a descobrir os diferentes tributos de Joaquim Reis. Sempre criticando e questionando de forma generosa e preciosa. Indicando a luz para poder realizar a minha foto.

Miguel Chaia, sempre atencioso, disposto a ajudar, alertando caminhos a serem seguidos, apoiando minhas dificuldades na elaboração escrita.

Horacio Fernandes. O espanhol em plena montanha romana indicando o foco na minha fotografia.

Lucas Bambozzi, Eder Santos, meus fotógrafos do movimento.

Fernanda Zerbini (Leticia Queiroz), Manoel Hayne (Boris Tatlov), Bruno Baptistelli (Carvalho Andrade) e Lucia Reisewitz (Natasha Yeltsin) ajudando nos apertos, com boa vontade e disposição.

Bola, sempre ao meu lado, minha eterna diagramadora, minha companheira.

Andreas Gursky, com dicas preciosas e disponibilidade.

André Sobral, meu eterno comandante e companheiro dos mares. Ajudou muito Joaquim Reis a descobrir as preciosidades do nosso litoral.

Marcelo do Campo, que abriu espaço para Joaquim Reis seguir o seu caminho.

Maria Vicentina Dick, minha encantadora professora, profunda conhecedora da toponímea indígena. 


\section{RESUMO}

Esta pesquisa procura analisar a obra do fotógrafo Joaquim Reis, que viveu no Brasil entre 1914 e 1930, período em que realizou vários registros e experiências no campo da imagem fotográfica.

Fotografia de registro, influenciada pela pintura de paisagem. Fotografia industrial, testemunho objetivo.

Experimentos com a fotografia.

Experimentos com o filme (a fotografia em movimento).

Contato com experimentos da vanguarda Européia, unidos a próprias experiências práticas.

Analisar os pensamentos sobre a capacidade da fotografia, ser um aparelho reprodutivo e verificar suas consequências.

Verifiquei textos de Walter Benjamin que observam o condicionamento técnico da aparência da aura.

\section{PALAVRAS-CHAVE}

Registro fotográfico, máquina de reproduzir, testemunho objetivo, experimento. 


\section{ABSTRACT}

This research looks to analyse the work of the photographer Joaquim Reis who lives in Brazil between 1914 and 1930, period where it accomplished some registers and experiences in the field of photographic image

The photographic register, influenced for the landscape painting. Industrial photography, objective cerification.

Experiment with the photography. Experiment with the film (photography in moviment). Contact with experiments of the European vanguard, joined the proper experiences pratice.

To analyse the thoughts on the capacity of the photograph, to be reproductive device and to verify its consequences.

I verified text of Walter Benjamin that observe the condition technician of the aparence of the aura.

\section{KEYWORDS}

photographic register, schemes to reproduce, objective certification, experiment. 
sumário

09

introdução

12

fotografia de registro ou pintura de paisagem

18

fotografia industrial - testemunho objetivo

32

novas tentativas com o uso da fotografia

experimento com o filme

57

encontro com Marc Ferrez.

antes do photoshop

61

não existe conclusão 72

diario de viagem

73

diario de anotações

75

referências bibliográficas

76 




\section{INTRODUÇÃO}

No ano de 2005 permaneci alguns dias no Rio de Janeiro, realizando registros de Igrejas Barrocas e do Real Gabinete Português de Leitura, para um projeto que tinha uma relação sobre edificações que representassem o poder para um trabalho apresentado na $51^{\text {a }}$ Bienal de Veneza. Nessa ocasião, aproveitei a oportunidade para fazer algumas visitas à Biblioteca Nacional e pesquisar imagens de fotógrafos que registravam a paisagem no final do século 19 e início do século 20.

Numa dessas visitas acabei encontrando registros, cadernos de anotações, assim como imagens da costa brasileira que eram diferentes dos demais registros.

Havia uma certa ordem em uma desordem. Os textos destas anotações eram alguns escritos em português, alguns em tupi e outros e alemão. De imediato fiquei impressionado com as anotações nestas 3 línguas unidas a imagens que me causaram estranheza e curiosidade.

\section{Quem era essa pessoa?}

Qual era o pensamento atrás desses registros fotográficos? Daquela paisagem estranha, unidos a anotações que utilizavam essas diversas línguas. Logo descobri nessas anotações, as siglas Joaquim Reis, que seriam de um fotógrafo com forte tendência antropológica e estudioso da língua e cultura tupi, chamado JOAQUIM REIS. Descobri que no final de todos os registros, principalmente no verso das imagens,
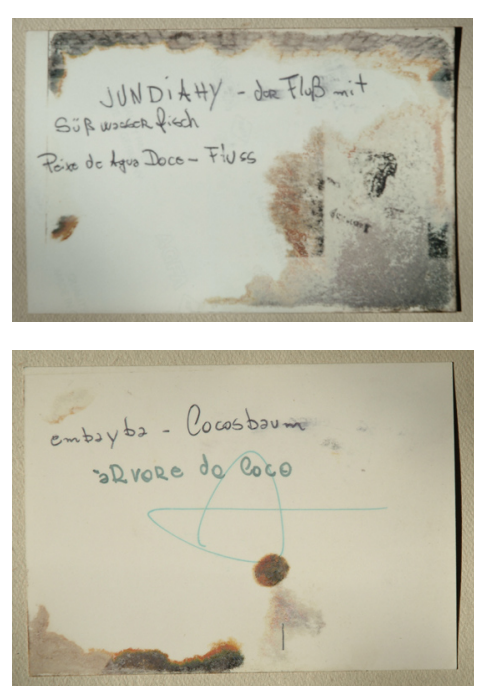
haviam anotações com a descrição, a data, o lugar da foto, a maior parte das anotações em tupi e algumas em alemão e português. Existia um determinado método que junto a descrição da palavra tupi, uma anotação sobre um determinado acidente geográfico. 
No meio de suas primeiras anotações encontrei um documento da antiga Agencia de Imigração Brasileira (DOC.AlB) com carimbo do Porto de Santos, datado em 9 de janeiro de 1914, em que também é descrito seu nascimento em Dresden, Alemanha, em 1894 e o nome Joachim Reis no lugar de Joaquim Reis. Encontrei também uma espécie de diário escrito em alemão em que estavam descritos os dias assim como a viagem que fez da alemanha para o Brasil (DIA VIA). O lugar de partida: Porto de Hamburgo seu destino seria o Rio da Prata.

Não encontrei informações de que Joaquim Reis tivesse seguido viagem, parece que ele resolveu ficar por Santos. Encontrei um diário de anotações (DIA ANOT) feitas em Bertioga, parece que ele permaneceu um tempo vivendo por lá. Durante o período em que viveu em Bertioga, encontrei vários registros relacionados a estudos de paisagem e também algumas correspondências com Marc Ferrez e anotações feitas a respeito desses encontros.

Talvez fosse esse o motivo de ter encontrado todo esse material junto ao material catalogado sobre a obra de Marc Ferrez na Biblioteca Nacional. O próprio material de Joaquim Reis vinha com uma sigla ANP/CCB, extinta Agência Nacional do Patrimônio e Cultura da Costa do Brasil. Alguma ligação dessa instituição com a obra de Marc Ferrez.

Ter encontrado essas anotações e imagens de Joaquim Reis, os lugares por onde ele passou, os tipos de imagens re10. Bertioga 1914

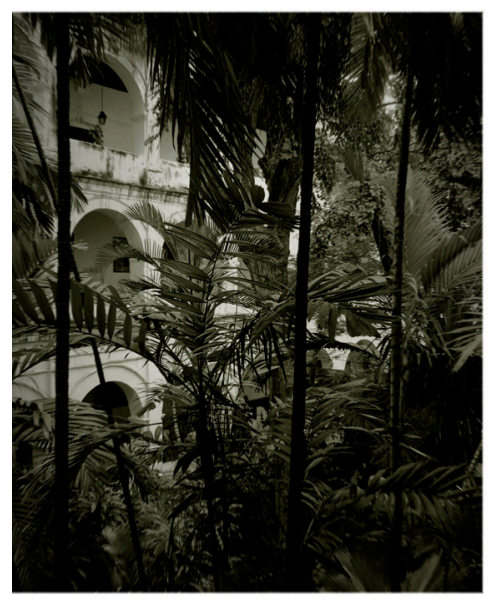

Vila de São Vicente 1914 gistrados, as anotações em tupi e alemão além do português ao lado do material de Marc Ferrez, foi para mim a justificativa de me envolver com esse material e fazer disso a minha pesquisa de mestrado na Universidade de São Paulo. 


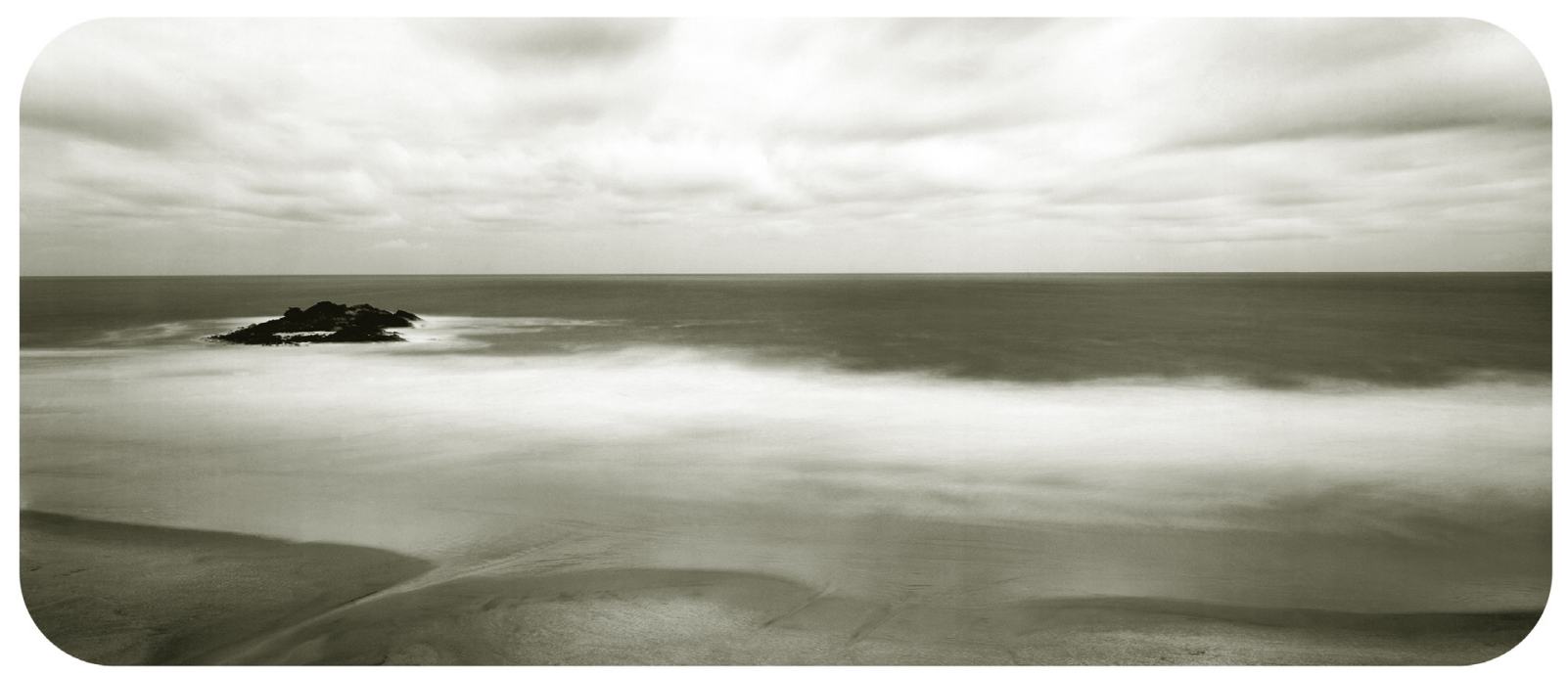




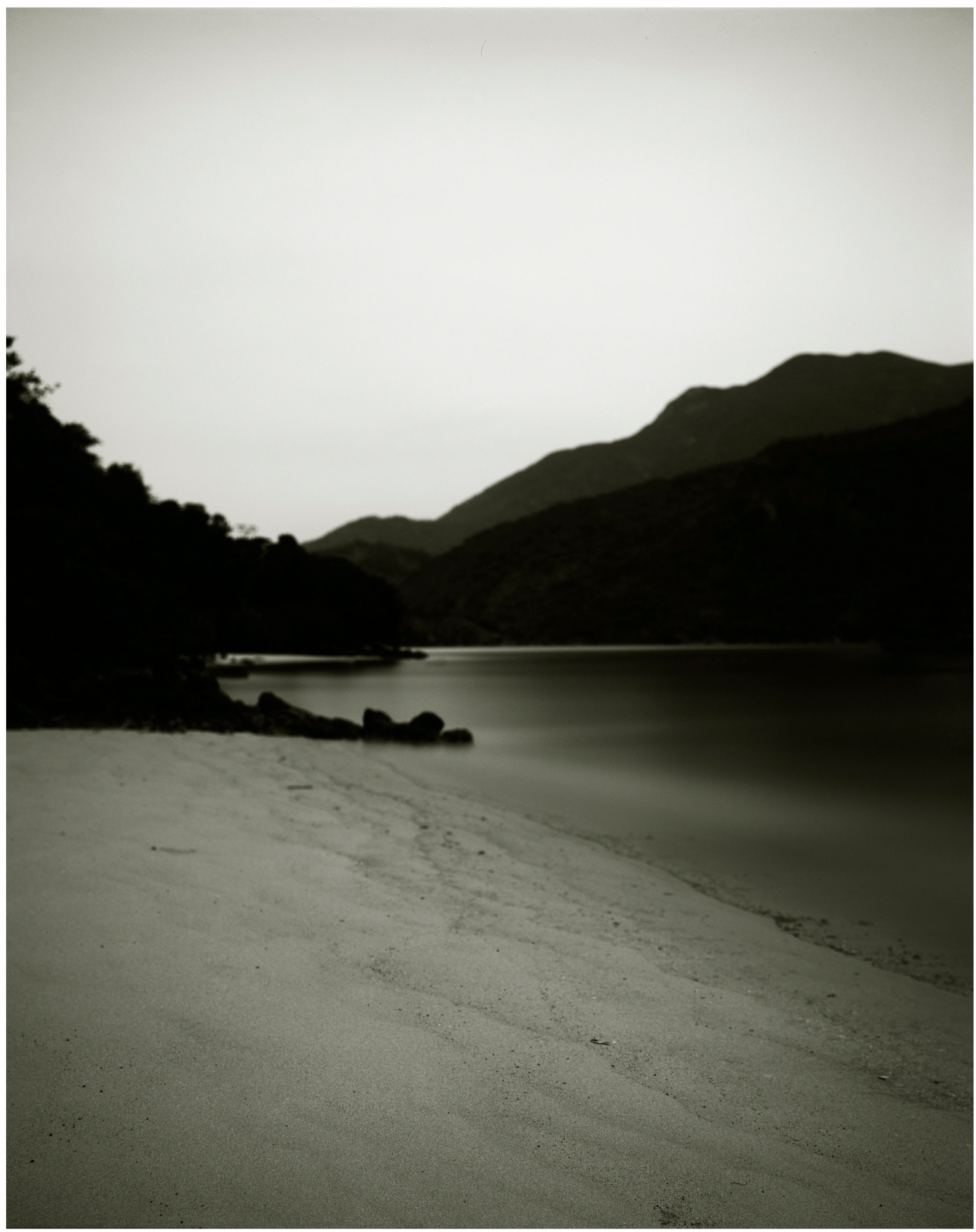




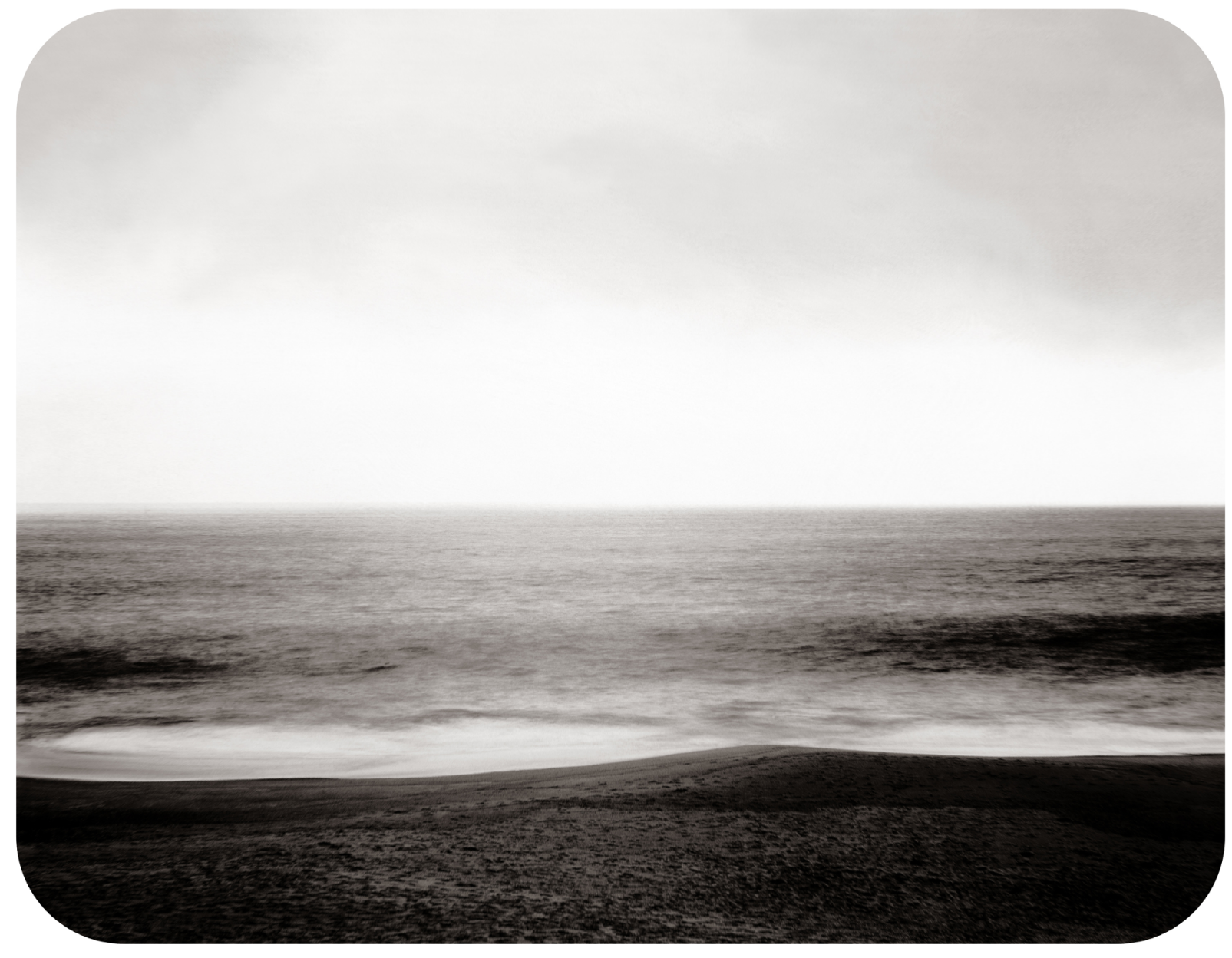




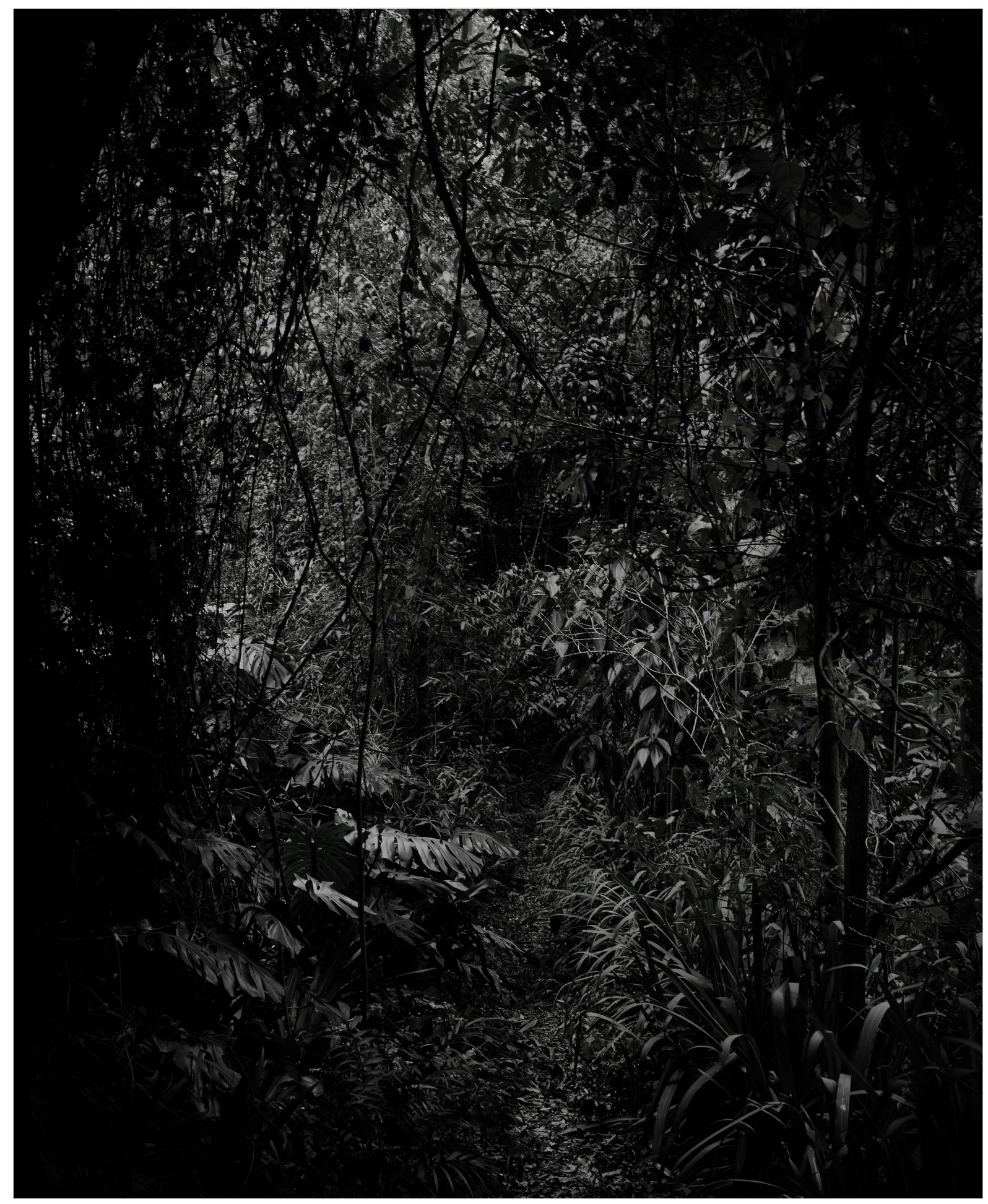




\section{FOTOGRAFIA DE REGISTRO OU PINTURA DE PAISAGEM}

Joaquim Reis nasceu em 1894 em Dresden, Alemanha. Em 1908, com 14 anos muda-se para Berlim onde faz curso profissionalizante na então renomada escola de fotografia, Lette Verein. Em 1914 com o crescimento de conflitos na Europa que levaram a dar início à $1^{a}$ Guerra, o jovem fotógrafo Joaquim Reis foge da obrigação militar, e então aos 20 anos de idade, vai ao Brasil levando o endereço de Rudolf Lanz um professor amigo de seus pais que vivia em Bertioga, influenciado pela obra de Hans Staden que fazia um estudo sobre a cultura dos povos indígenas do litoral brasileiro: os Tupiniquins e os Tupinambás.

Joaquim Reis traz junto a sua bagagem ao Brasil, seu equipamento fotográfico, uma camera de filmagem (nunca usada), alguns escritos de Walter Benjamin, publicados em revistas que circulavam em Berlim nessa época (nunca lidos).

Joaquim Reis chega ao Brasil em 22 de abril de 1914. Vive durante um tempo em Bertioga com Rudolf Lanz. Conhece André Sobral, navegador português que possuia uma embarcação a vela. Viaja com André para fazer pesquisa pelo litoral influenciado pelos estudos que Rudolf Lanz fazia a respeito da cultura tupi e da geografia do litoral paulista e carioca.

Nesse momento realiza uma série de registros fotográficos em diferentes regiões do litoral norte paulista e do litoral sul carioca (registros sem encomenda de algum cliente, apenas uma pesquisa, um trabalho pessoal) influenciado pela idéia romântica: "tenho de me render ao mundo que me rodeia, unir-me as suas nuvens e pedras, para poder ser aquilo que sou. Preciso da solidão para poder me comunicar com a natureza" - Caspar David Friederich. 
Joaquim Reis realiza o ensaio CAÇAPAVA - corr. Caáaçapaba, clareira ou aberta na mata; travessia da mata (Teodoro Sampaio. O Tupi na Geografia Nacional, pag 210 - Ed. Brasiliana) - acerca do pensamento Der Wald, A Floresta. Influenciado também pelo primeiro encontro com a literatura de Walter Benjamin: "tendo-se contemplado longamente uma tal fotografia, reconhece-se quanto os contrastes se tocam: a mais exata técnica pode conferir ao resultado um valor mágico que uma imagem pintada nunca poderá possuir" (W B Kleine Geschichte der Fotografie, Pequena História da Fotografia, pag 118, Relógio d’Água - Lisboa).

Joaquim Reis vive "um namoro com a luminosidade tropical” (Aracy Amaral, Contribuição de Segal, pag 57, Arte Para Que? A preocupação da arte Brasileira 1930 -1970, Itaú Cultural).

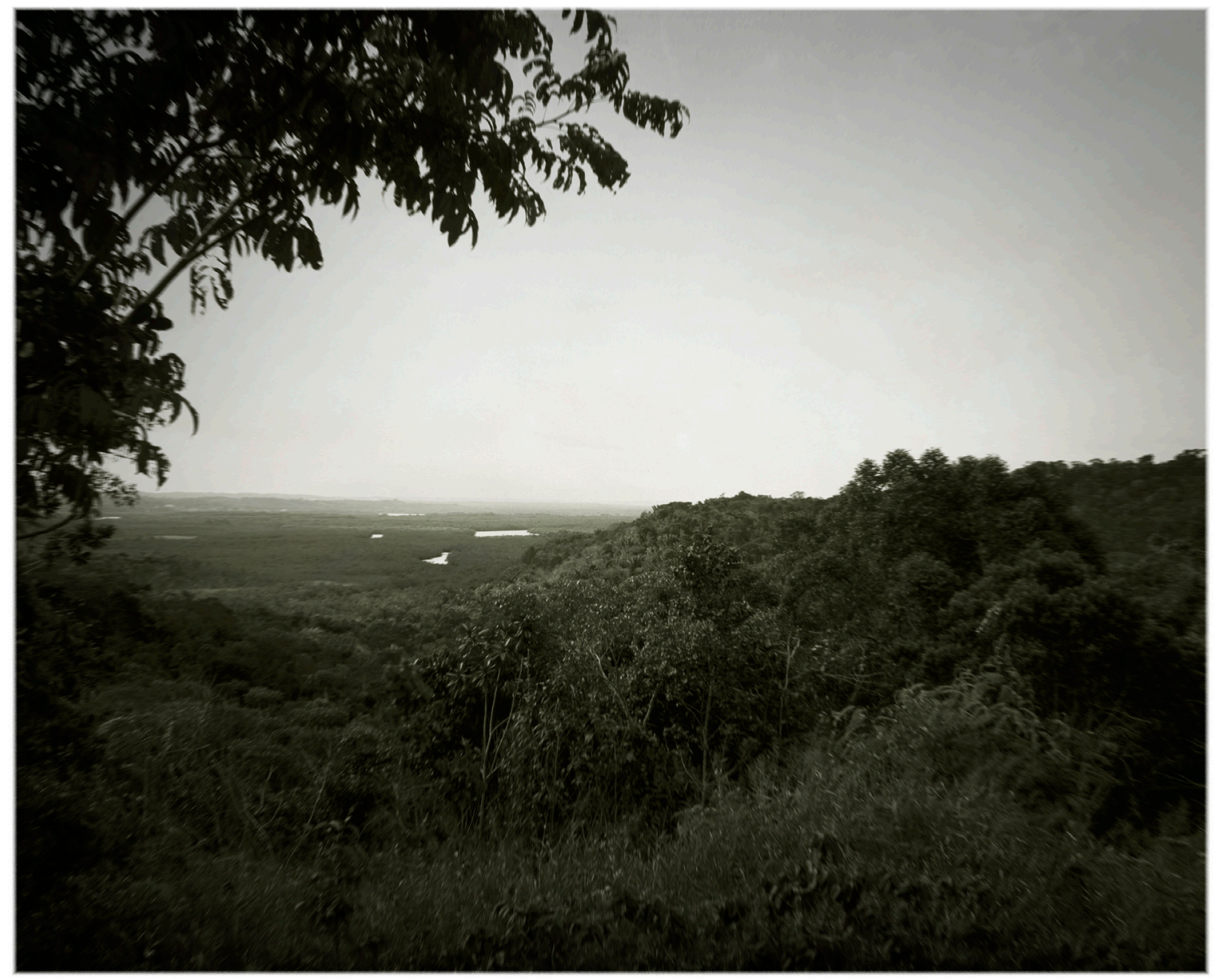




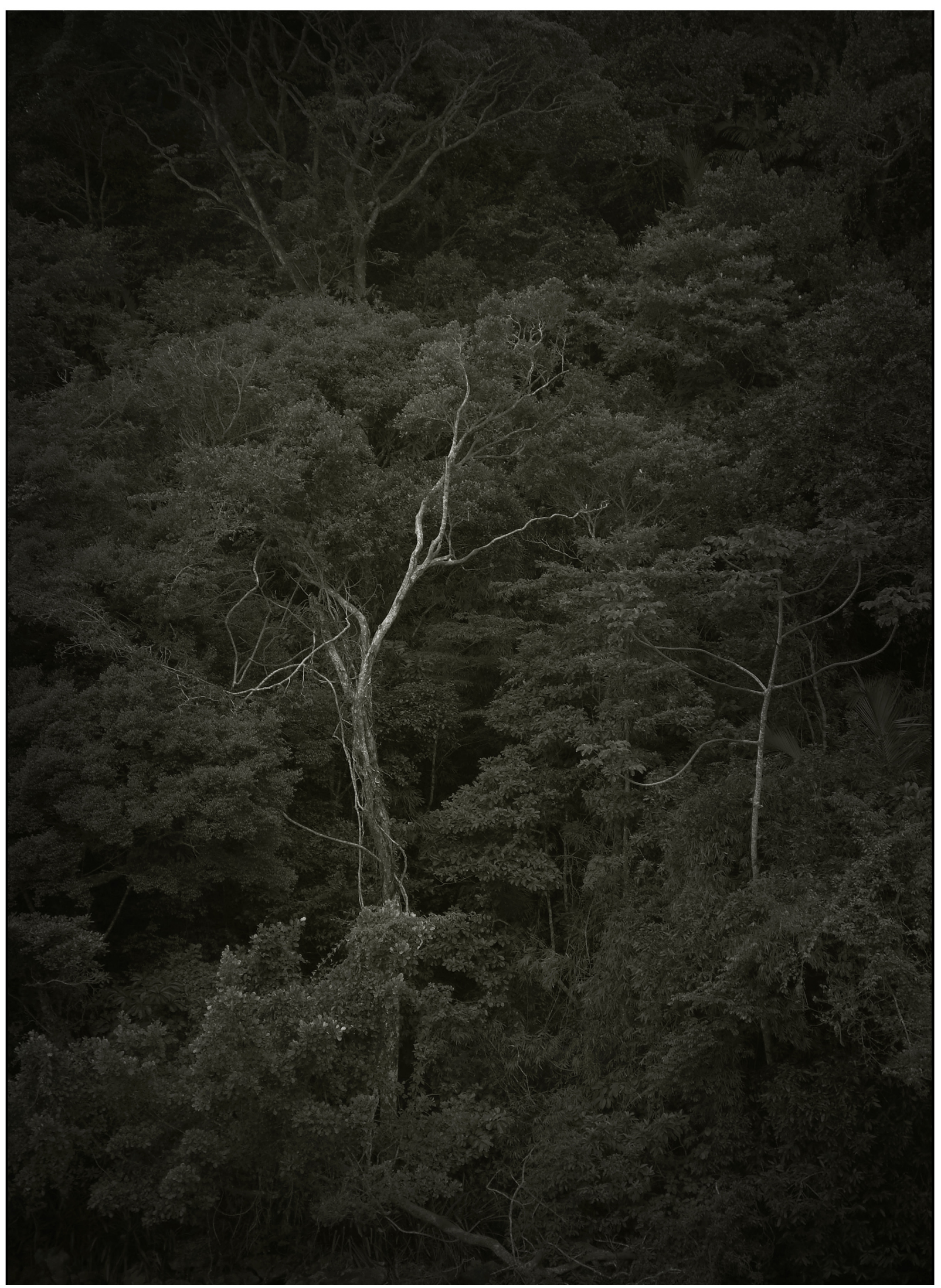




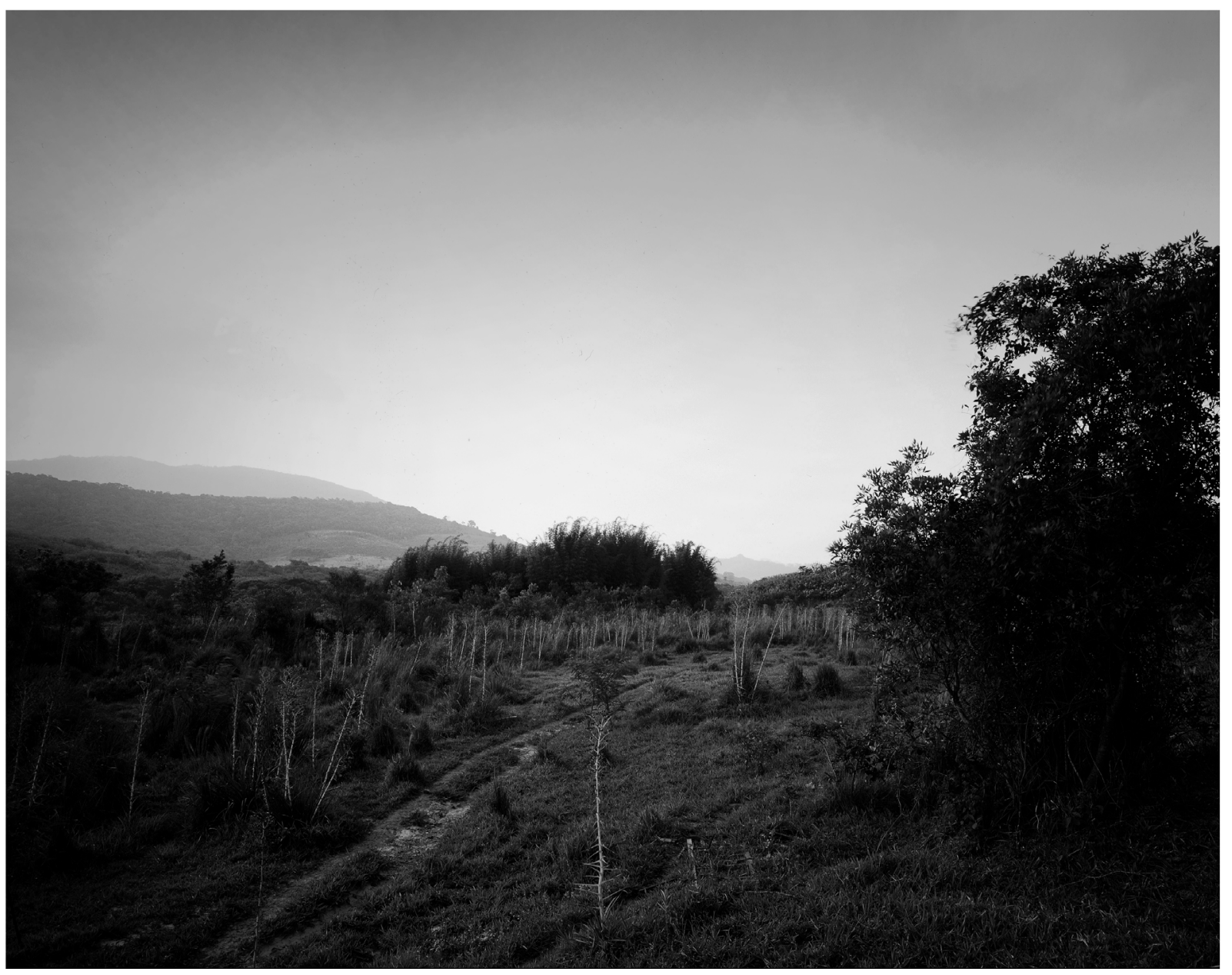





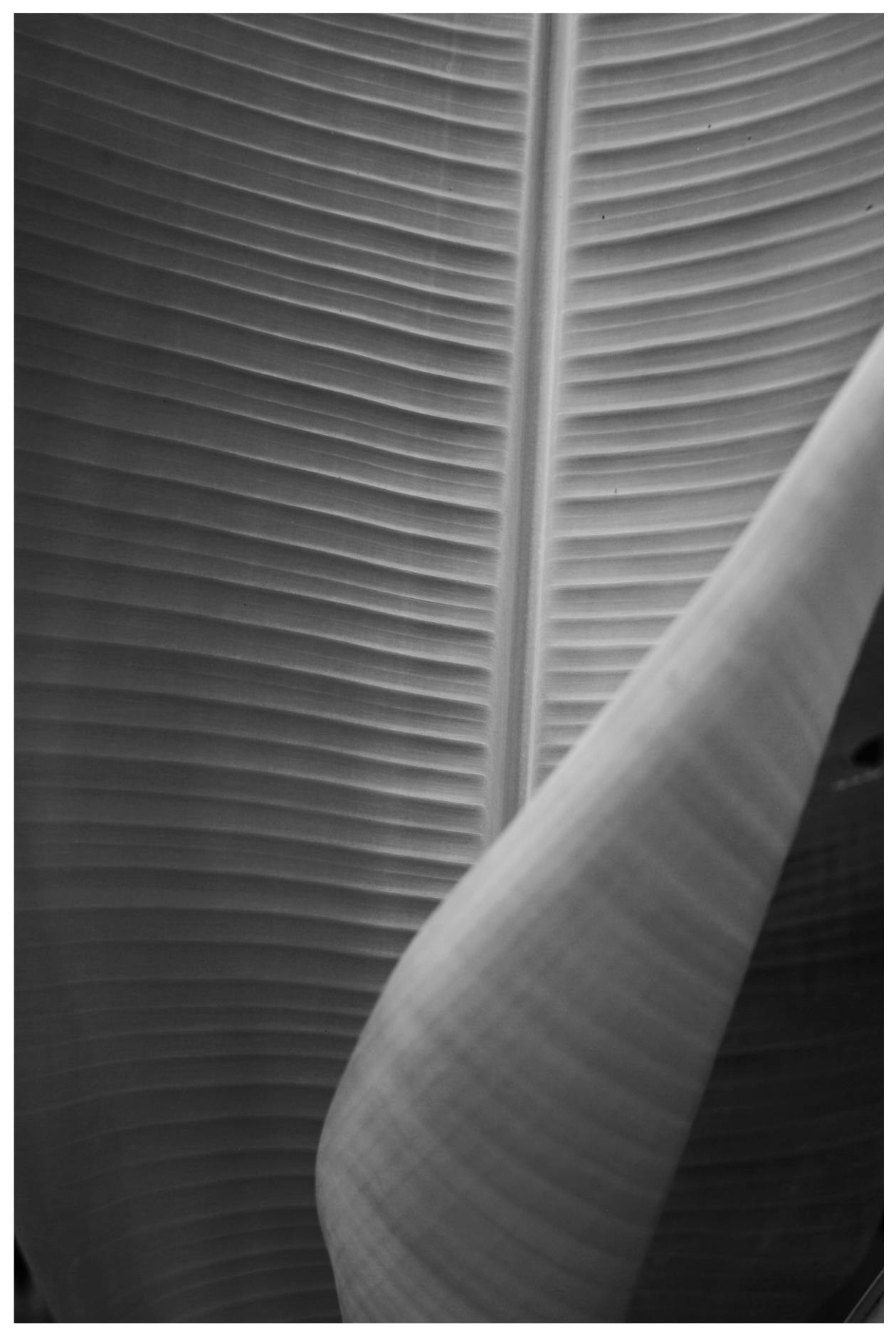




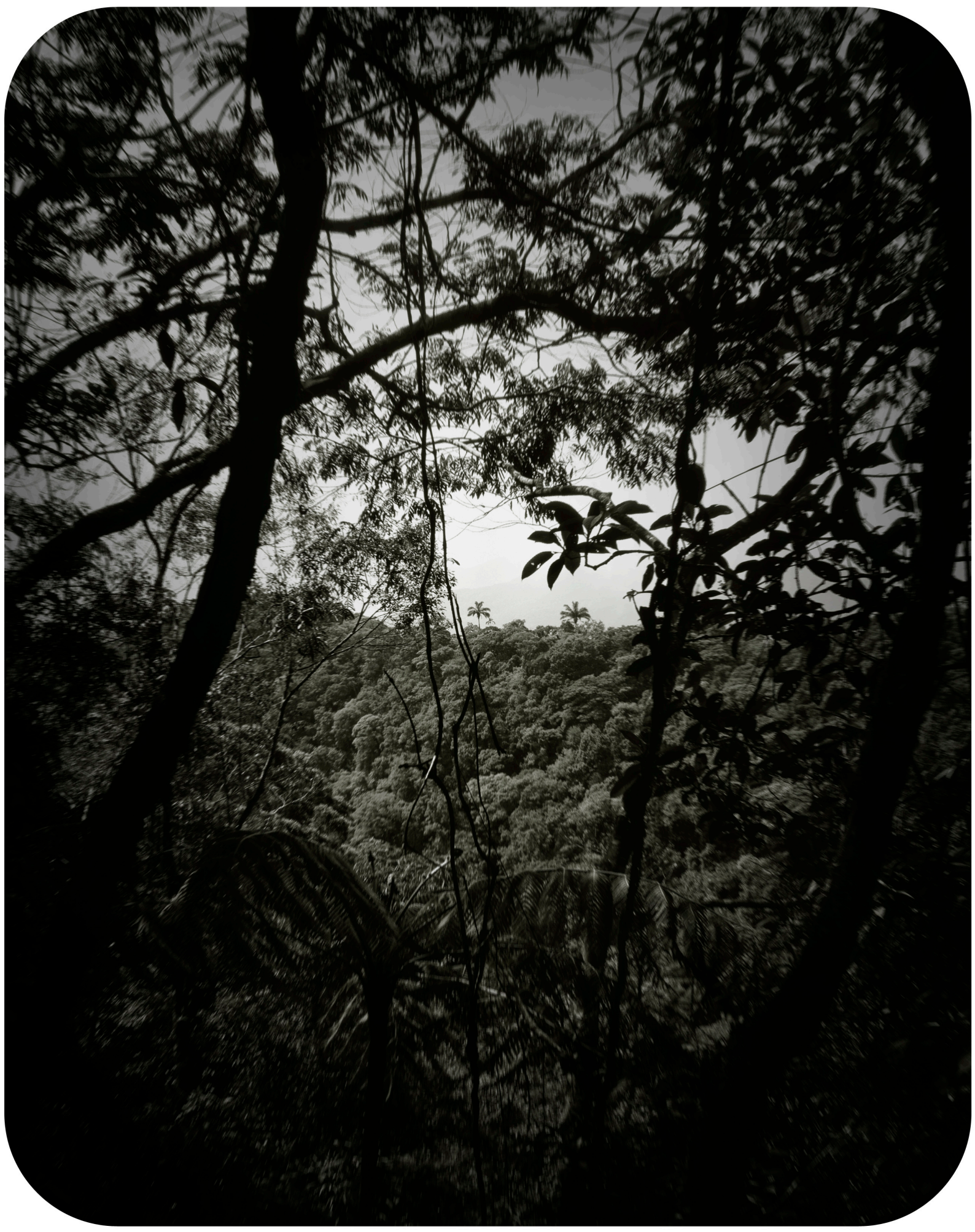




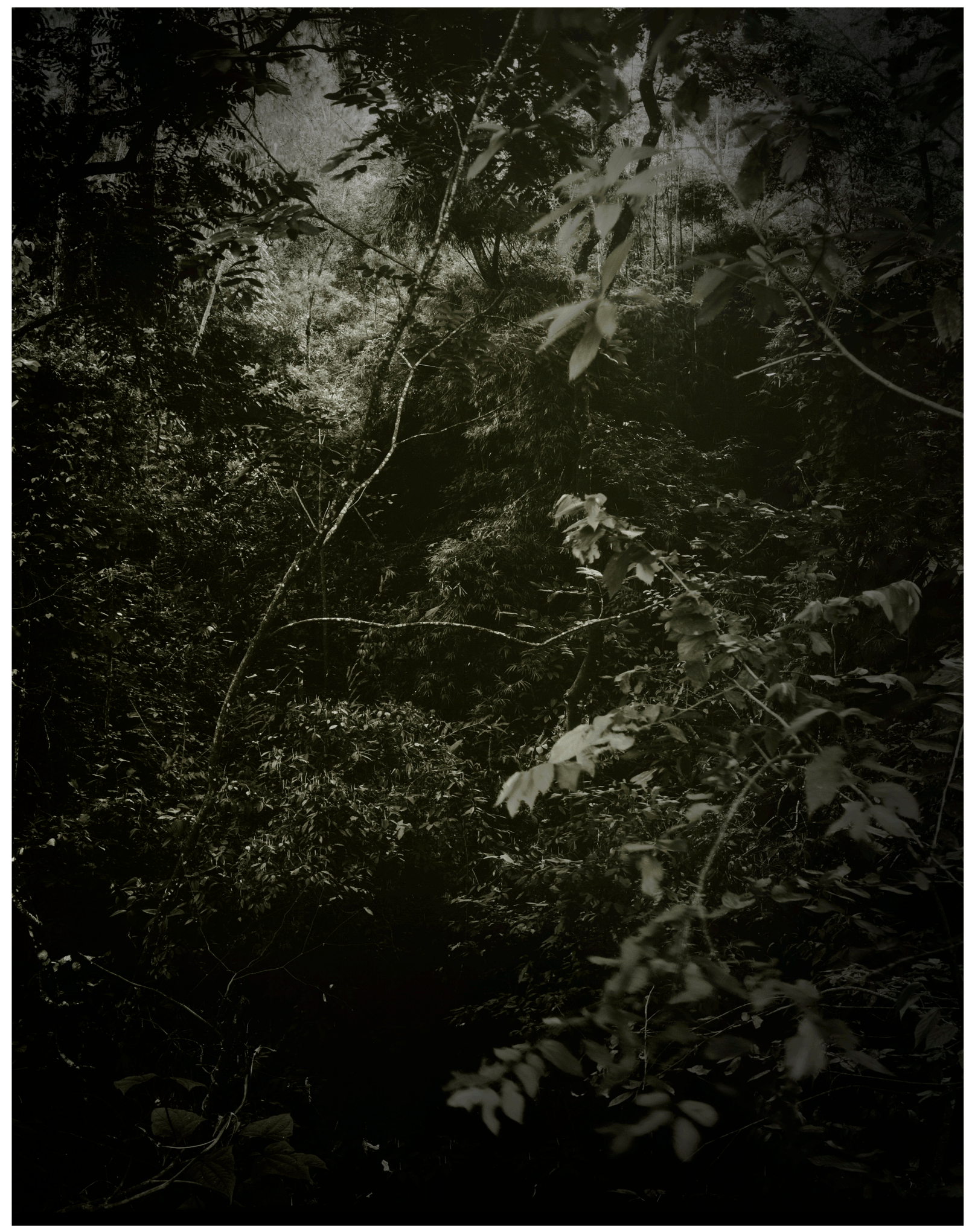




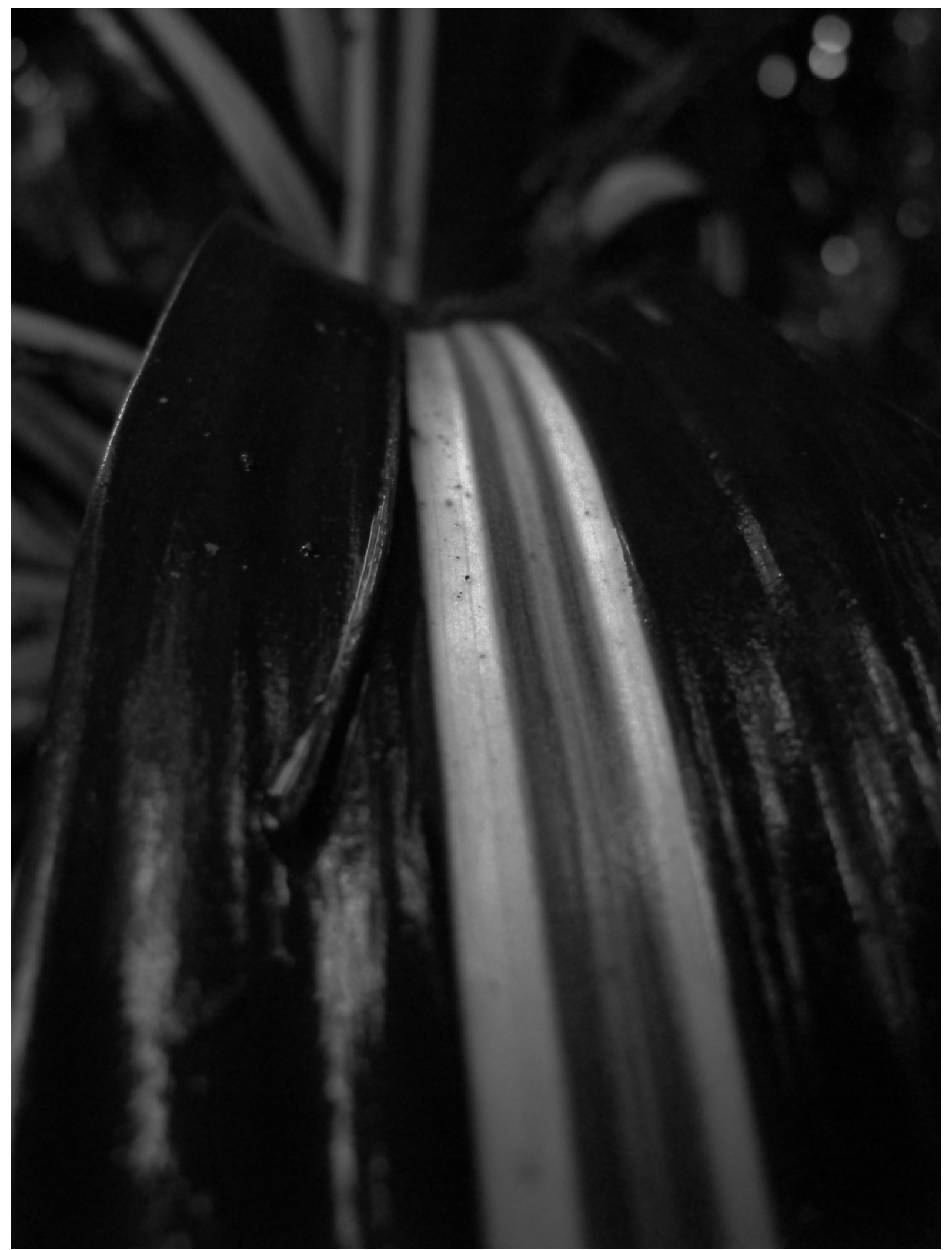




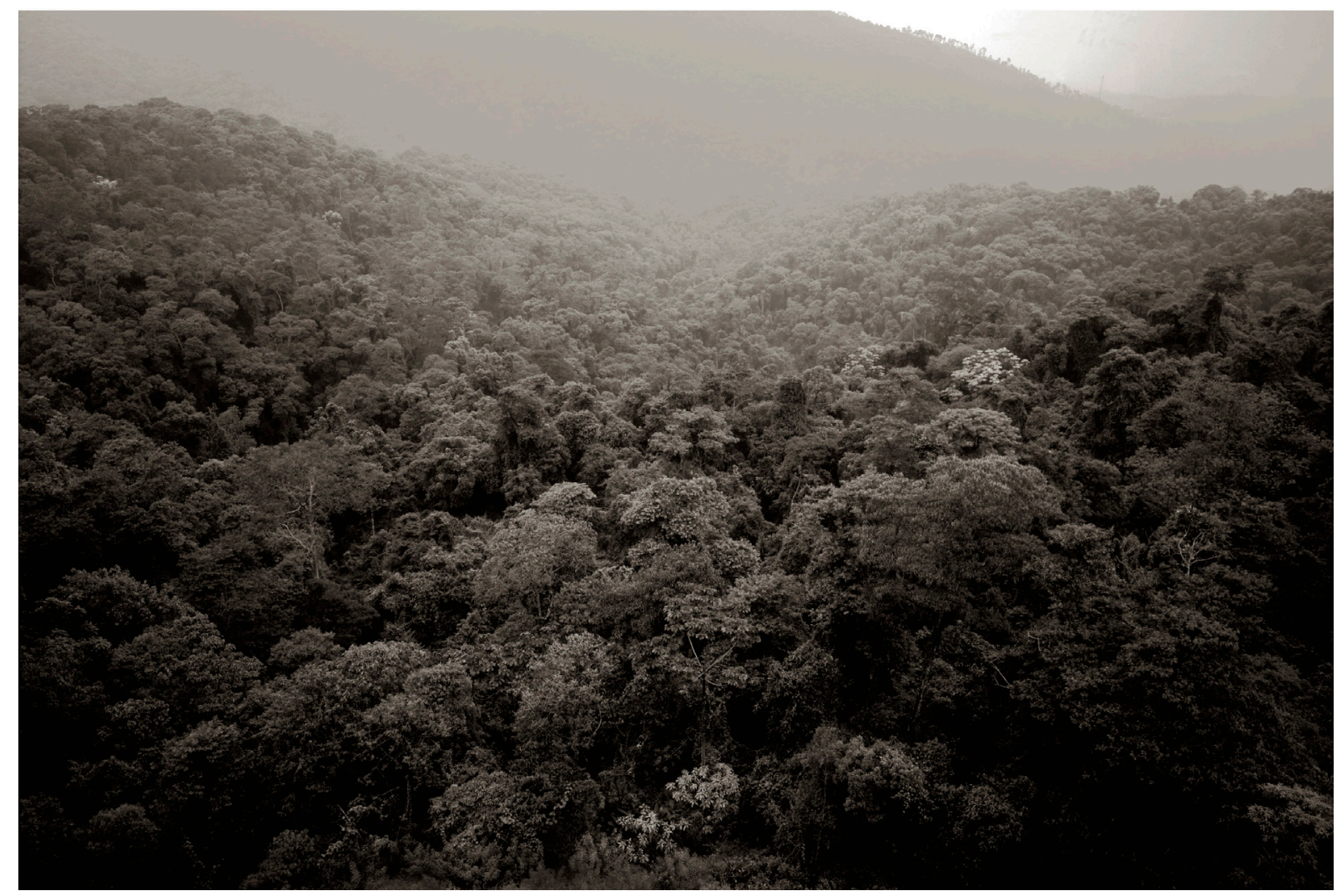




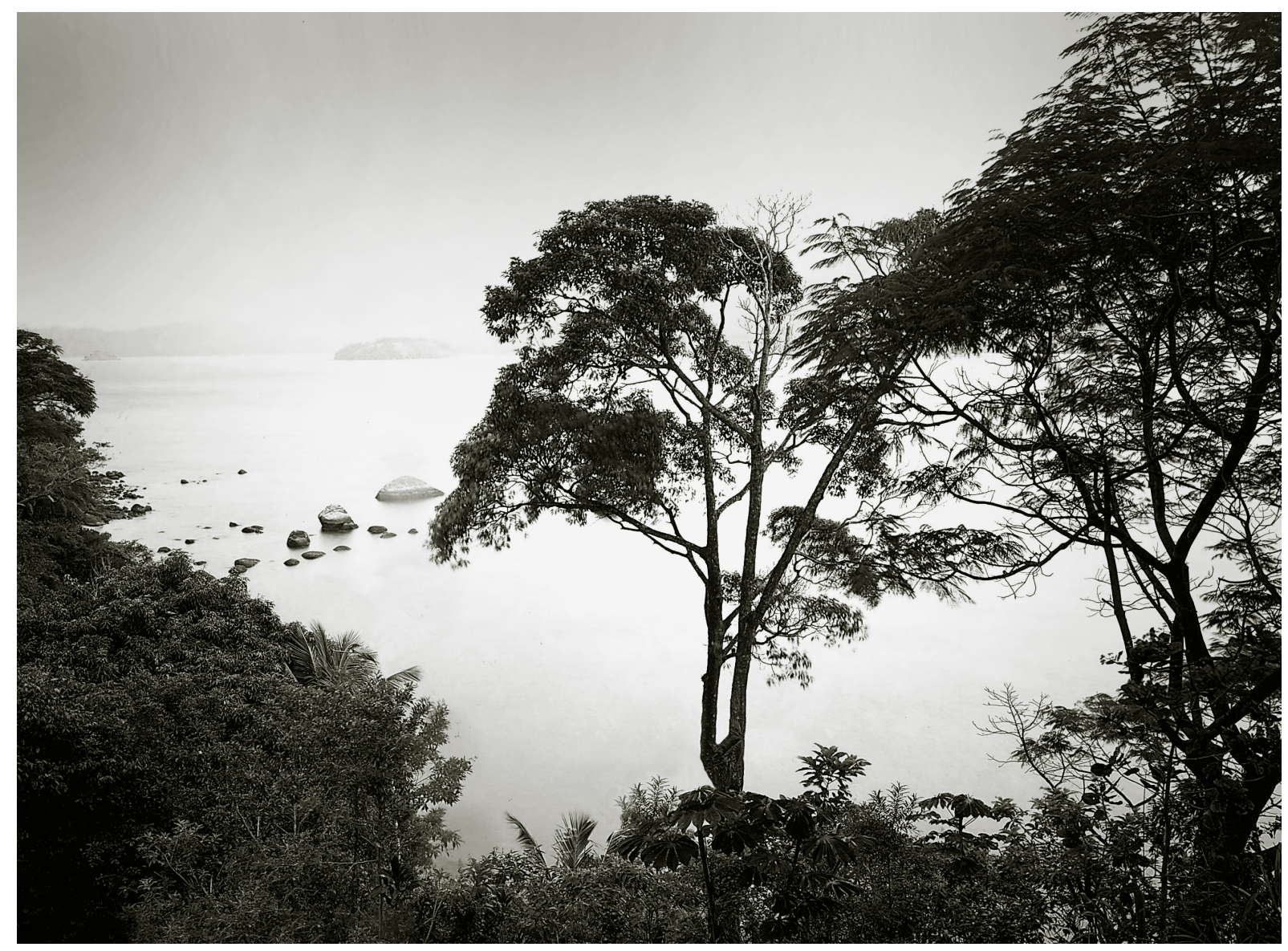




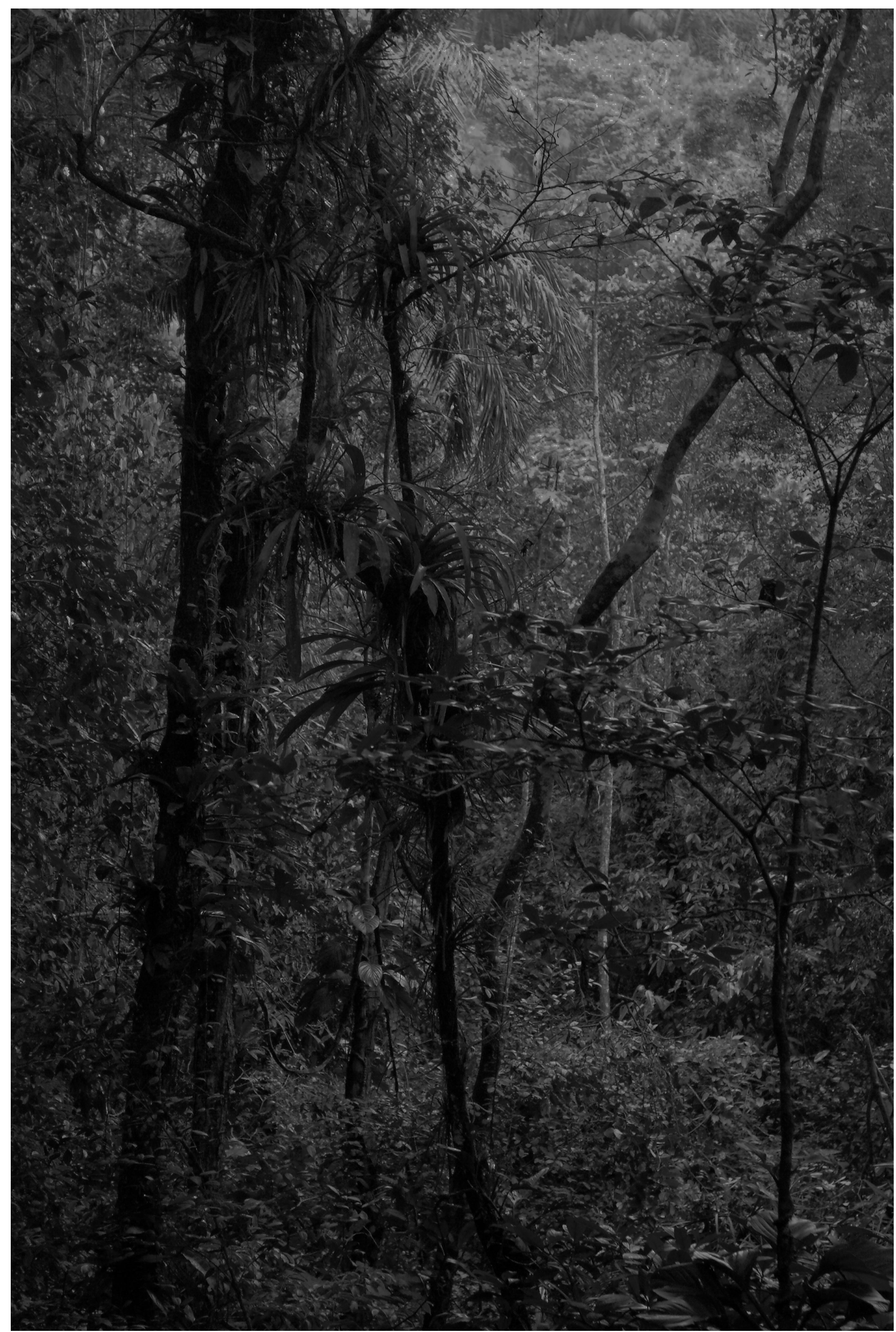




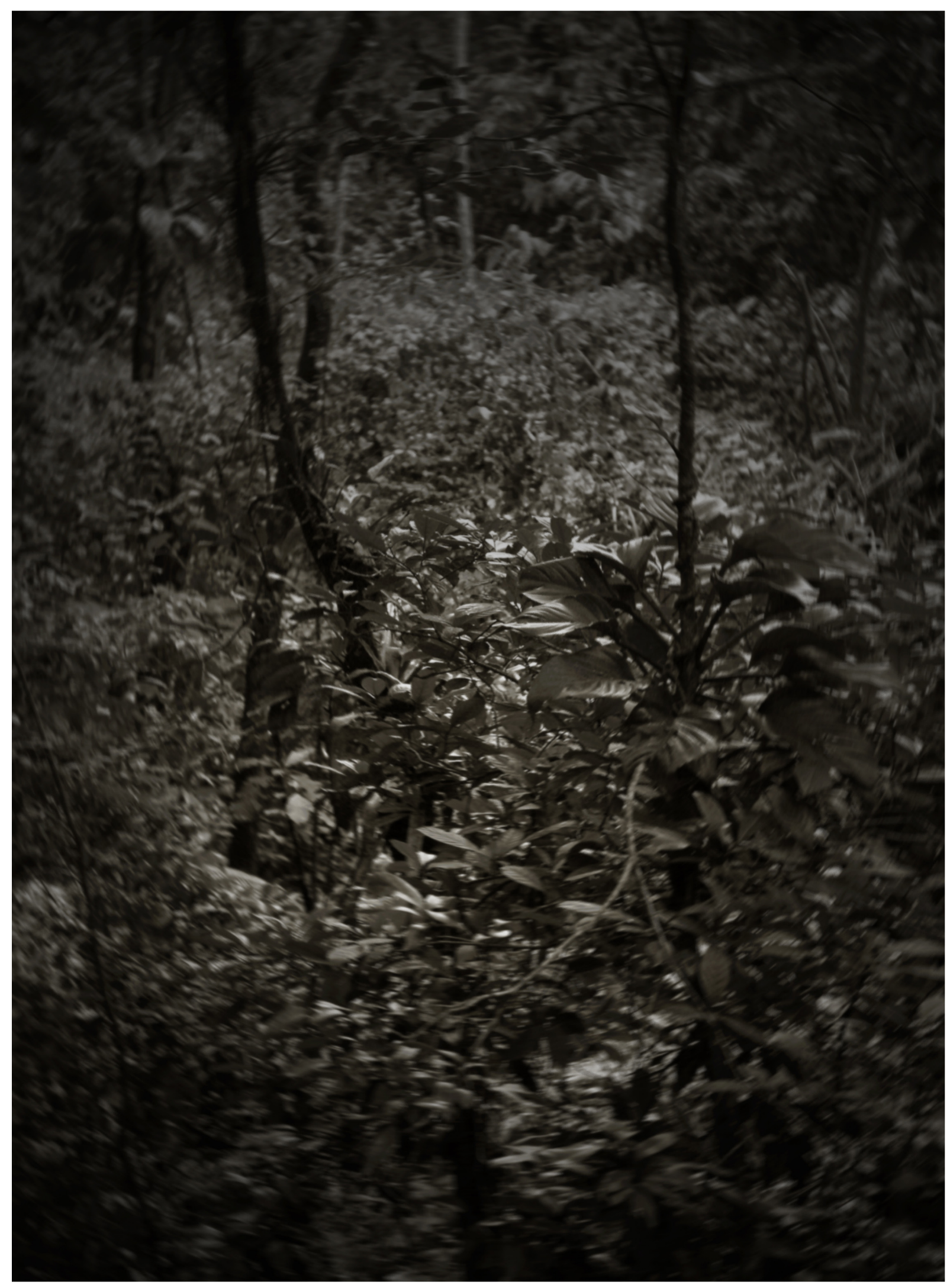




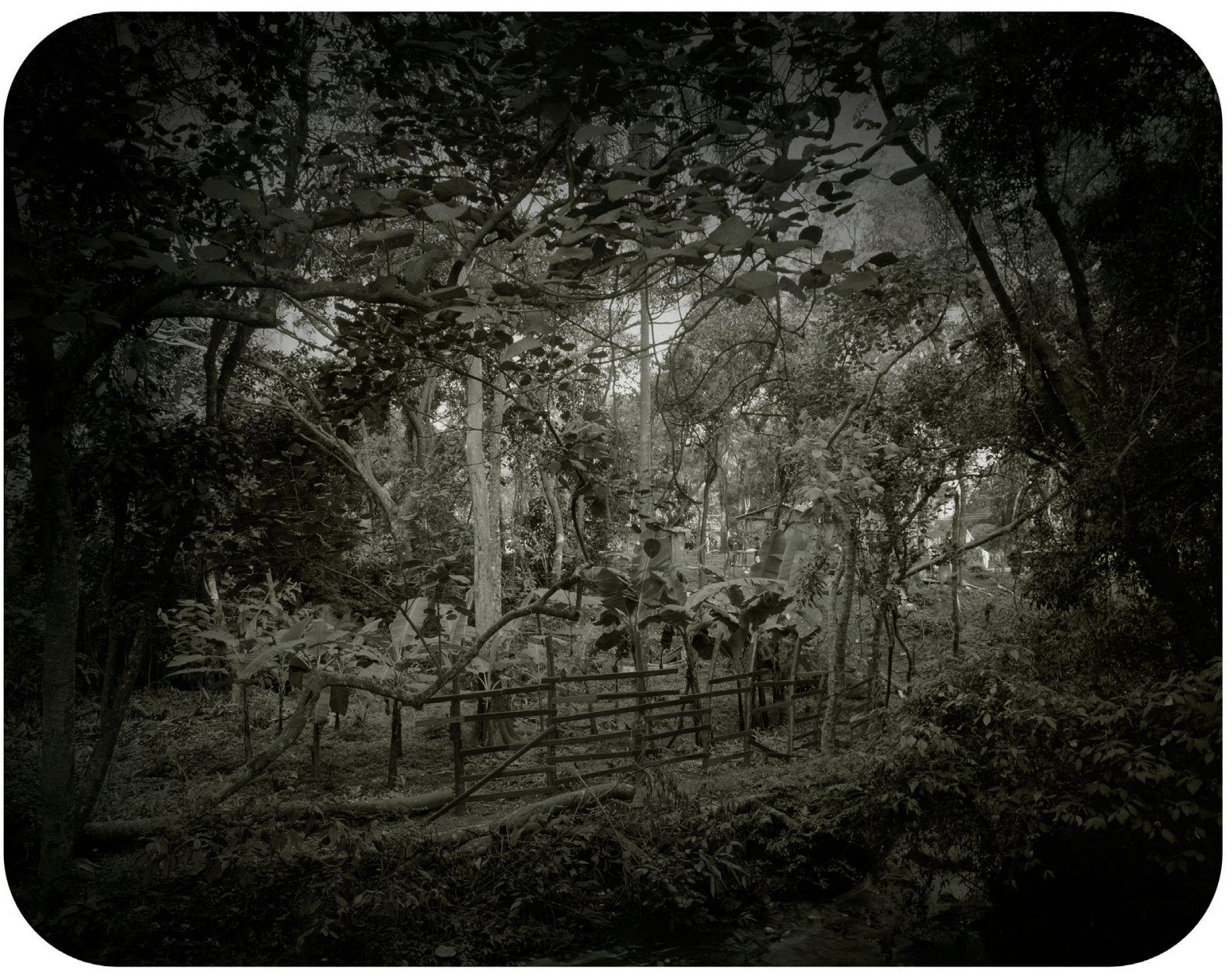




\section{FOTOGRAFIA INDUSTRIAL, TESTEMUNHO OBJETIVO}

Na primavera de 1914, Joaquim Reis vai a São Paulo, que vive novo ciclo da indústria "com a decadência da lavoura do café, época que muitos europeus vão para a capital fazendo surgir muitas indústrias" e se estabelece na rua Aurora 23 e inaugura seu ateliê de fotografia, Casa Joaquim Reis, especializando-se em fotografias industriais.

O nome Joaquim Reis e não Joachim Reis (assim o primeiro nome do fotógrafo "aportuguesado" por recomendação de profissionais da época).

Com o surgimento da nova era industrial e o início da produção em massa também em São Paulo, Joaquim Reis influenciado pela nova objetividade alemã, desenvolve um estilo de fotografia objetiva ligado ao pensamento de Albert Regner Patsch: "Deixemos a arte para os artistas e experimentemos com os meios da fotografia, realizar uma fotografia que com a qualidade fotográfica consiga existir".

Em 1917 realiza trabalhos para forjaria SIFCO em Jundiaí, SCHOEFFLER em Sorocaba, NGK em Moji das Cruzes e CBA Companhia Brasileira de Alumínio em Votorantim.

Desenvolve anotações ligados a um estilo de testemunho objetivo. "Sachbezogenen Aufnahmestill" e insere pensamentos relativos ao caráter das imagens "apesar de toda a habilidade artística do fotógrafo e da metodologia na atitude do seu modelo, quem contempla a fotografia sente o impulso irresistível de procurar, aqui e agora, o cintilar insignificante do acaso com o qual a realidade, por assim dizer, ateou o caráter da imagem, sente o impulso irresistível de encontrar o ponto singelo em que a existência de cada minuto há muito decorrido contém o vindouro e de forma tão convincente que nós, retrospectivamente, o podemos descobrir". (Walter Benjamin, "Kleine Geschichte der Fotografie" - Pequena História da Fotografia, Editora Relógio d’Água, Lisboa, pag 119).

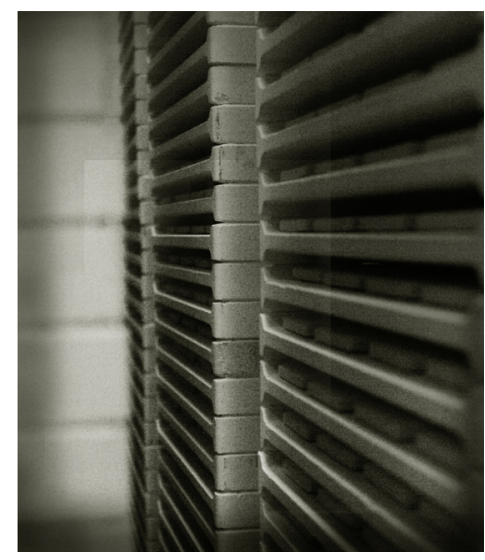

NGK, Mogi das Cruzes 1917

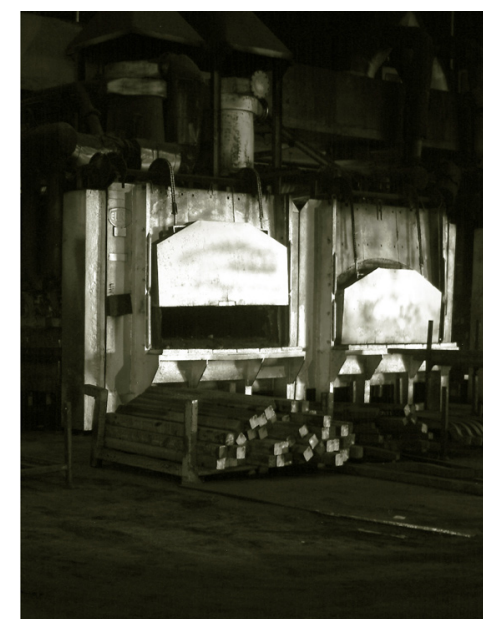

Forjaria SIFCO, Jundiaí 1917 


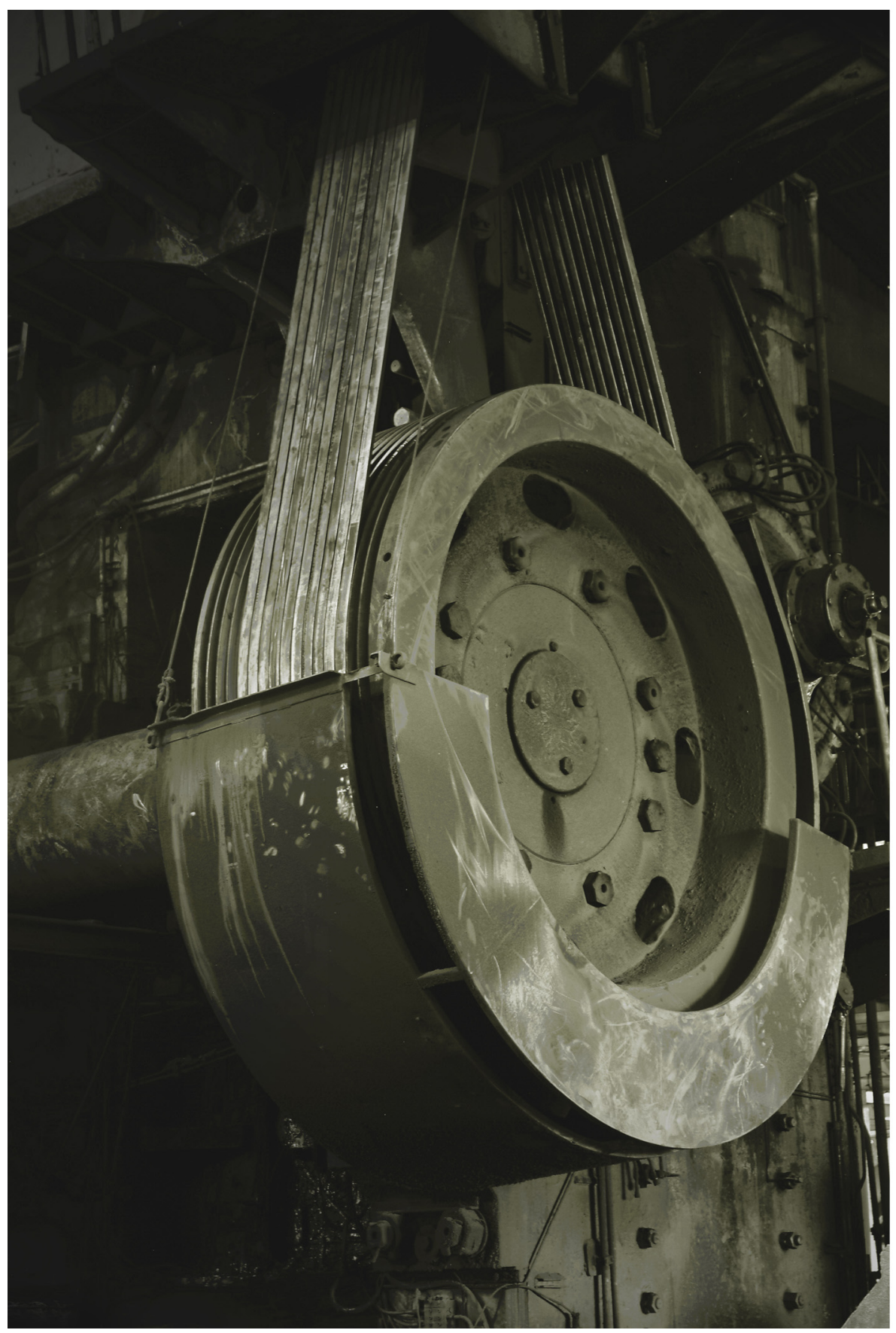




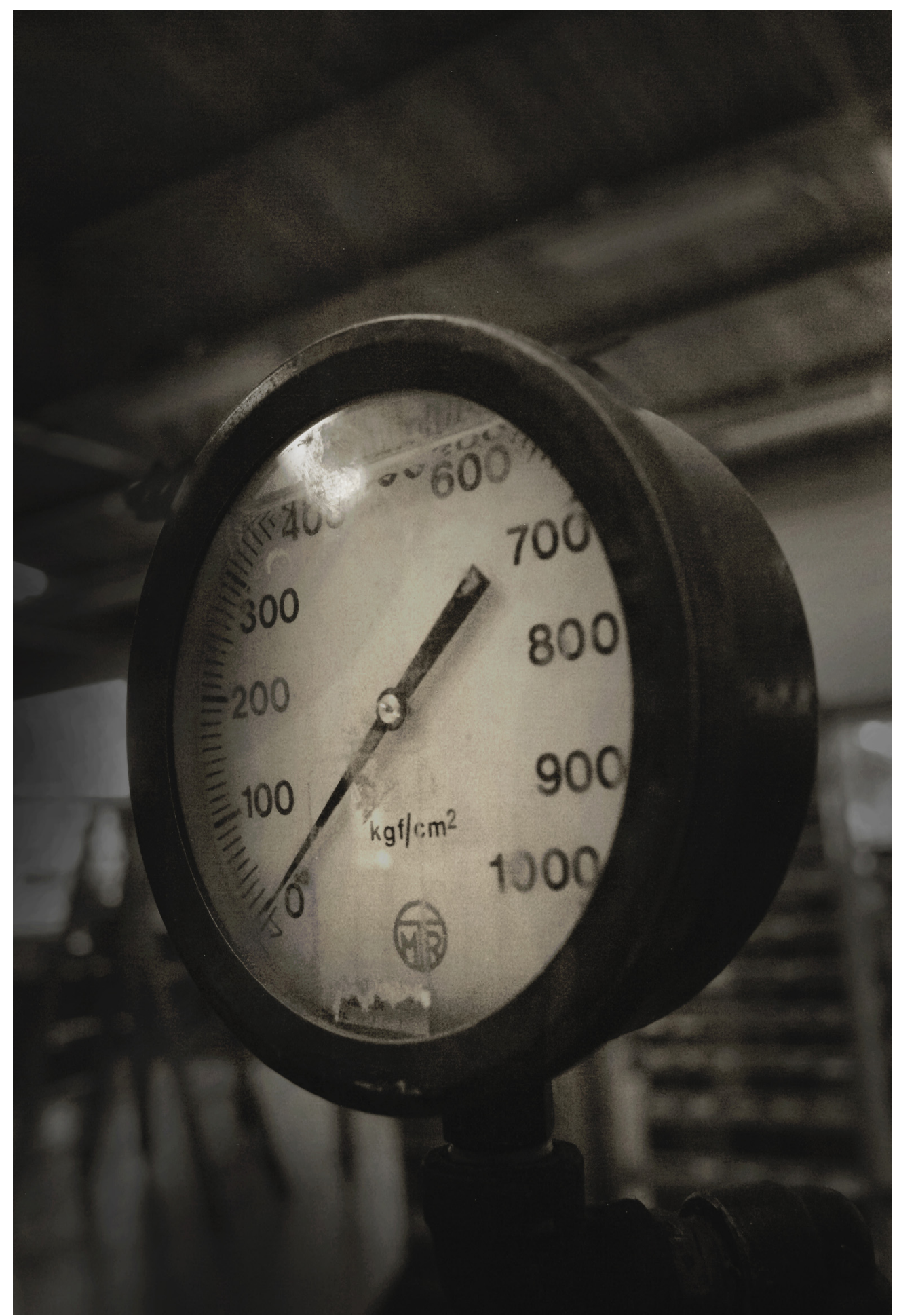




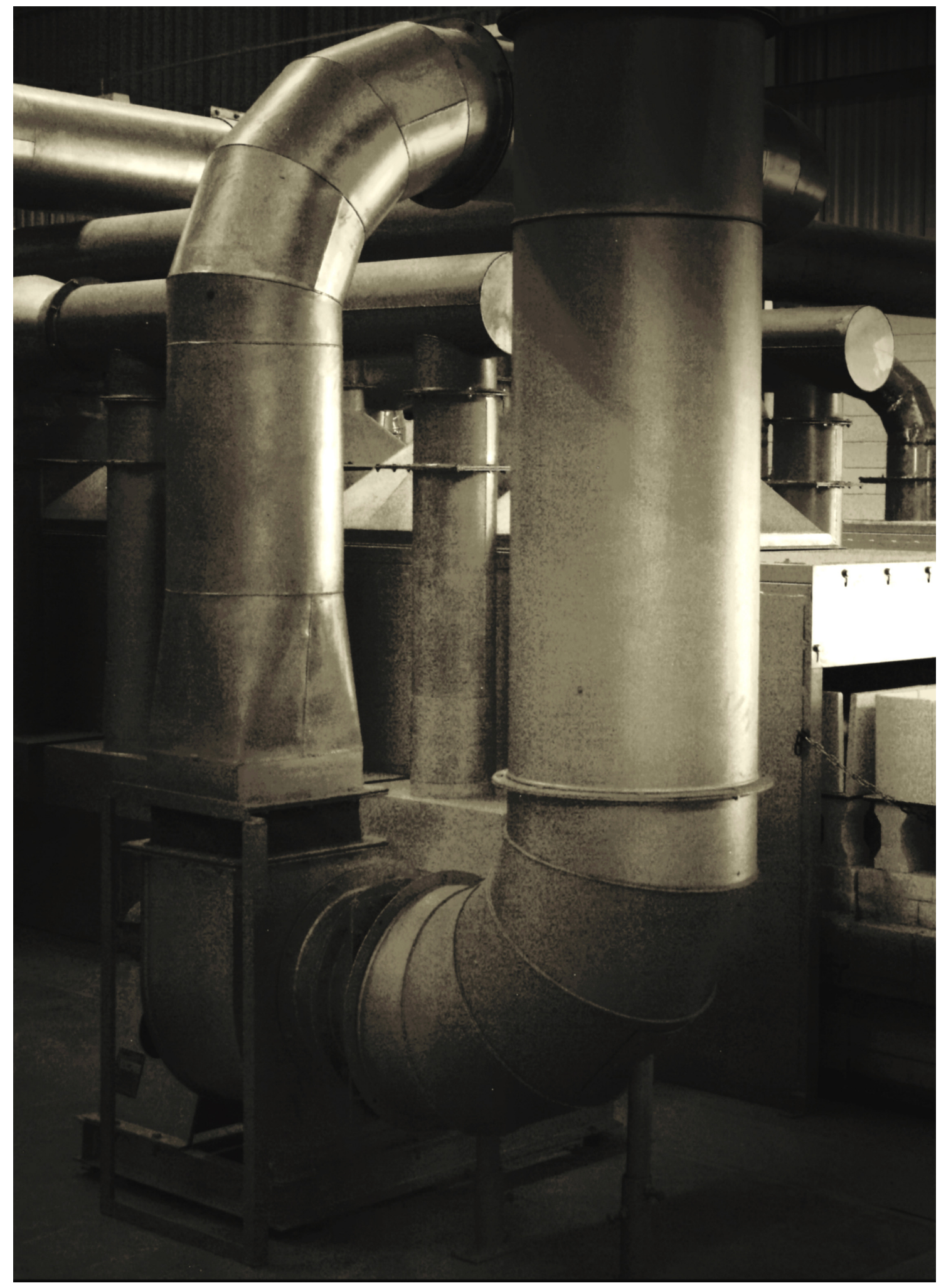




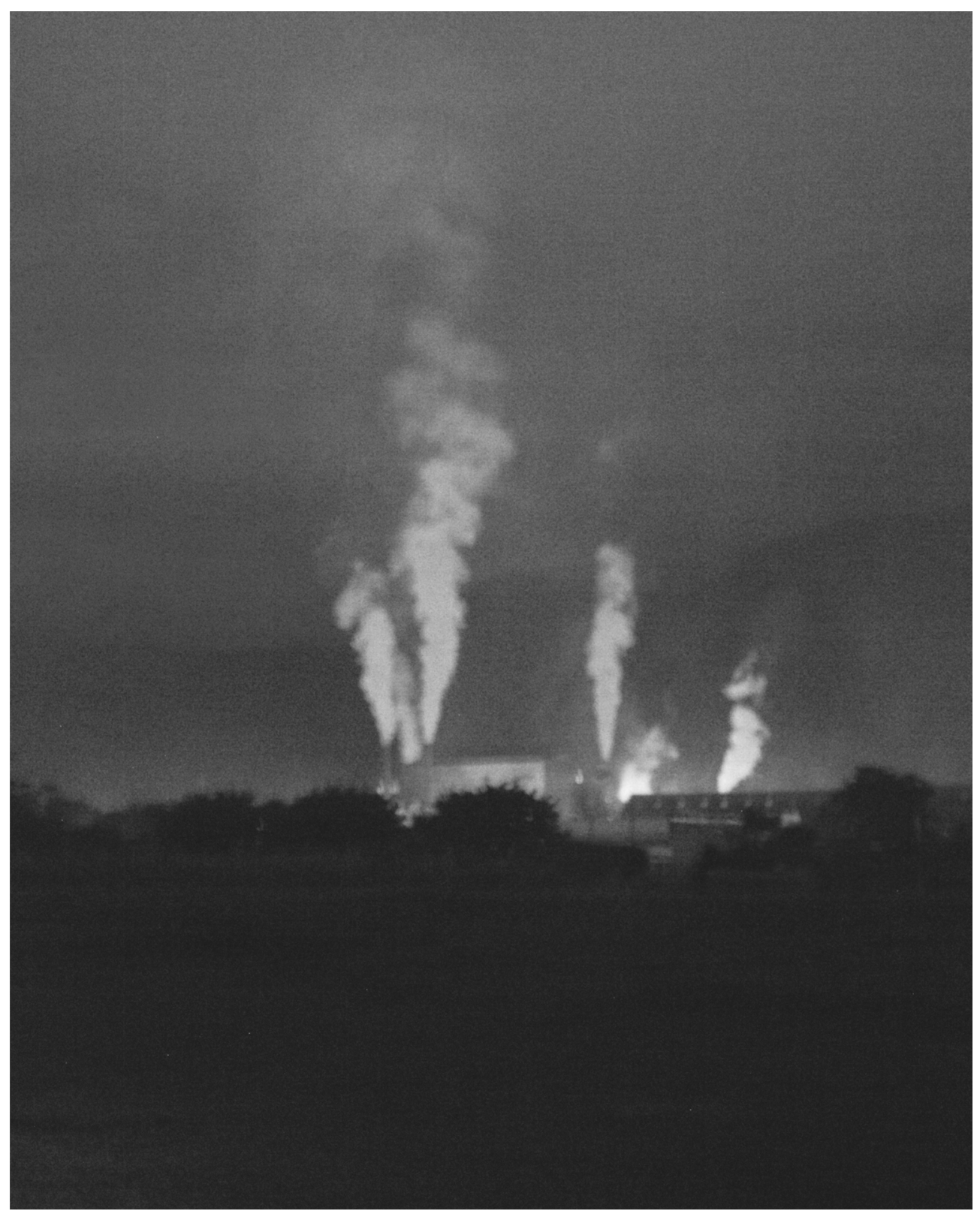





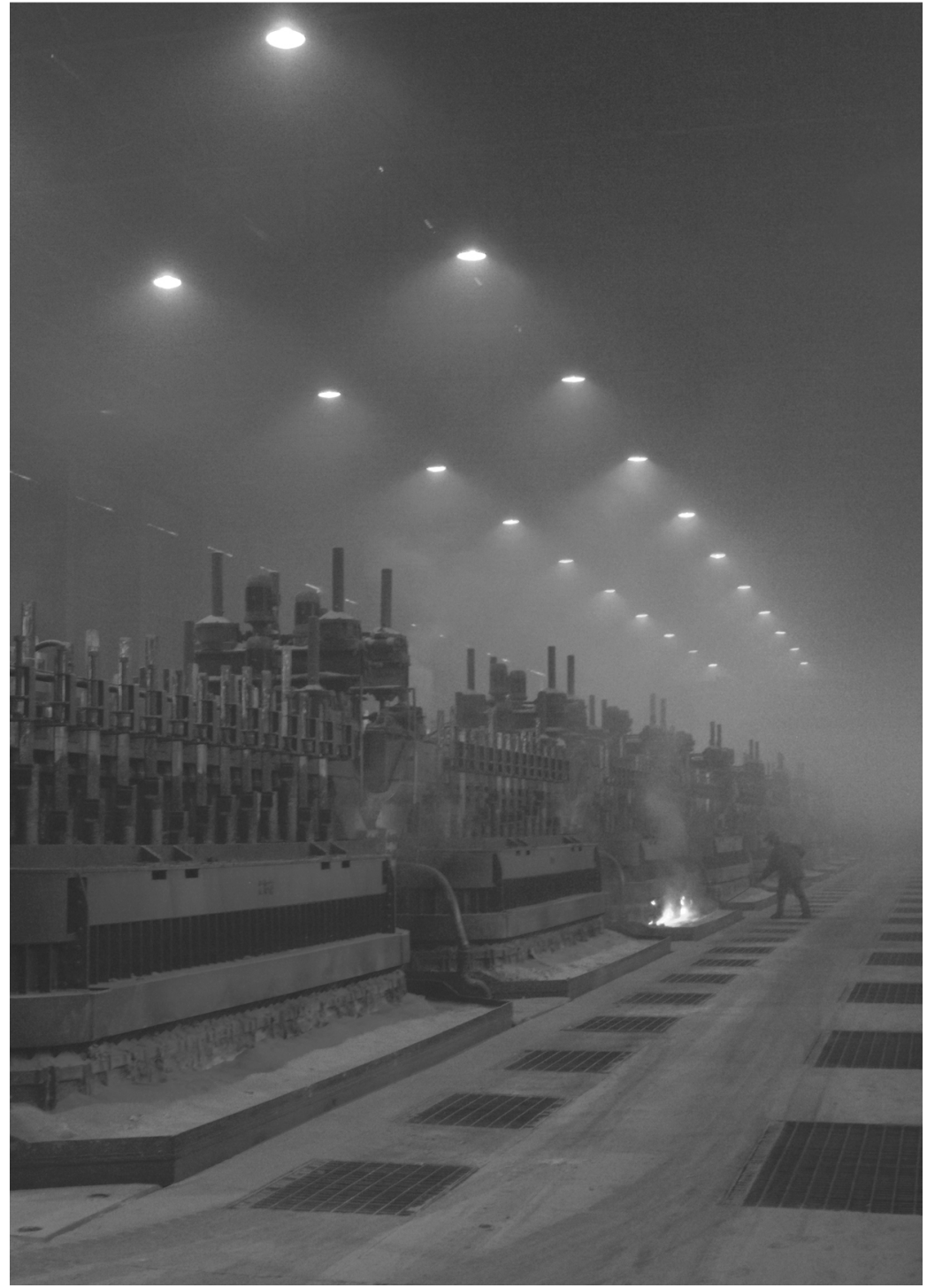




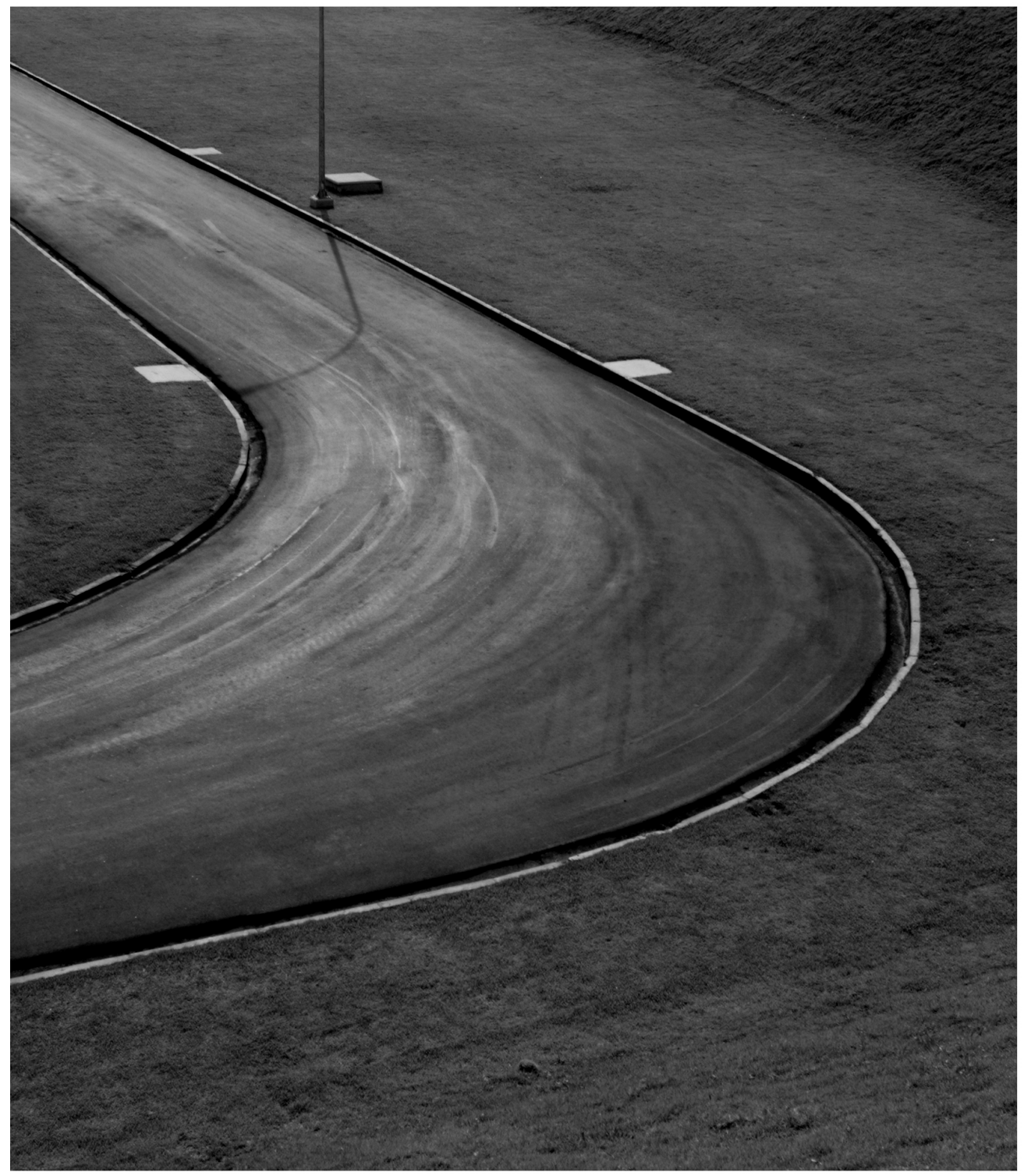




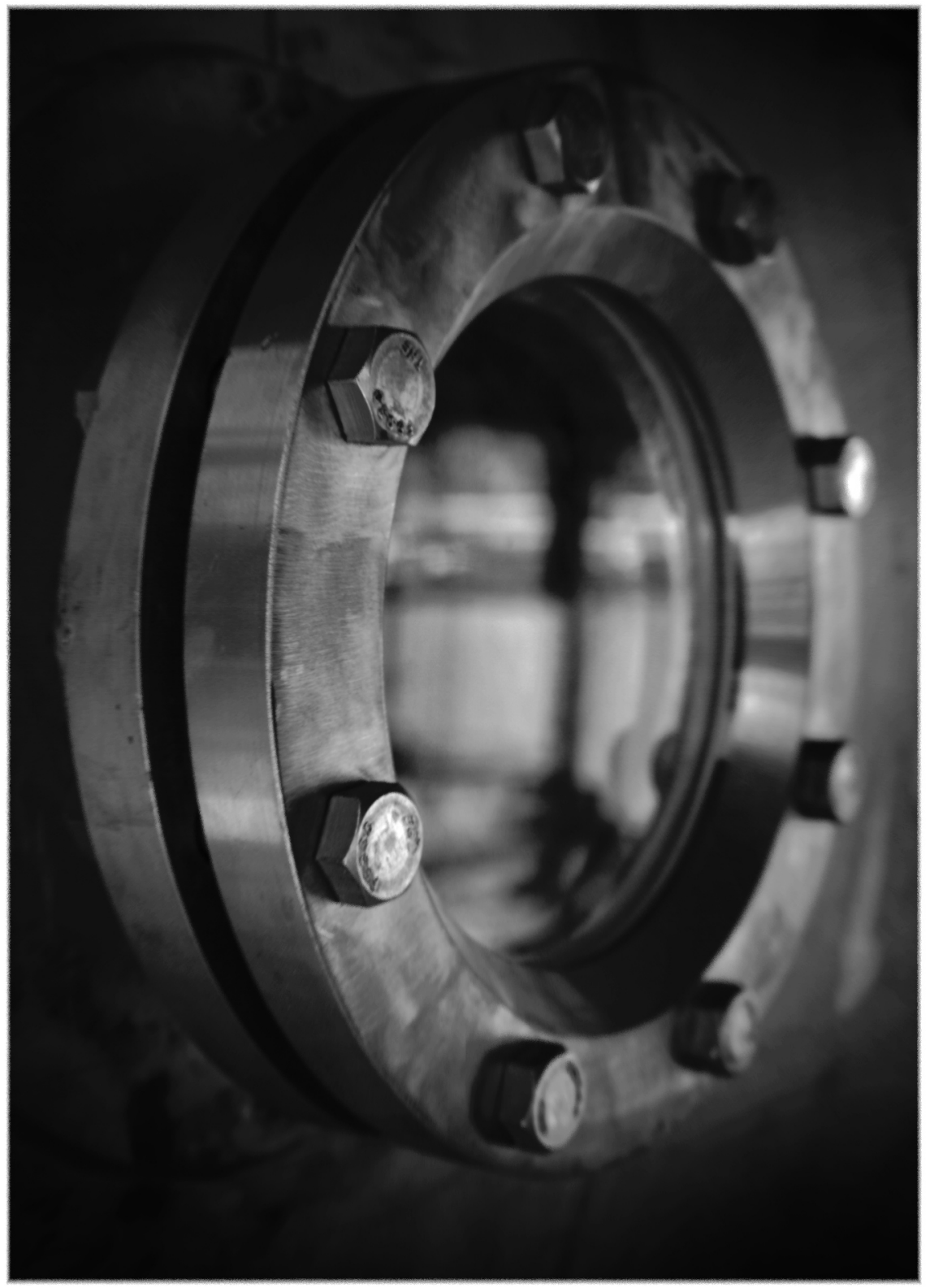

Votorantim 1918 


\section{NOVAS TENTATIVAS COM O USO DA FOTOGRAFIA}

Aperfeiçoando seu vocabulário português, Joaquim Reis, em 1919 entra em contato com alguns pensadores e escritores da época. Frequenta um grupo de estudos SPAM (Sociedade Pró-Arte Moderna). Conhece, o escritor Carvalho Andrade, a pintora Letícia Queiroz e o também escritor de origem Russa, Boris Tatlov. Com eles se reune e discute várias teorias relacionadas ao estudo da imagem escritas por Walter Benjamin em diversas revistas alemãs que recebia por correio de amigos de Berlim. Discutia também com intensa curiosidade a origem da linguagem e cultura Tupi. Por sua vez começa a se envolver em discussões relacionadas aos pensamentos dos artistas e intelectuais da época.

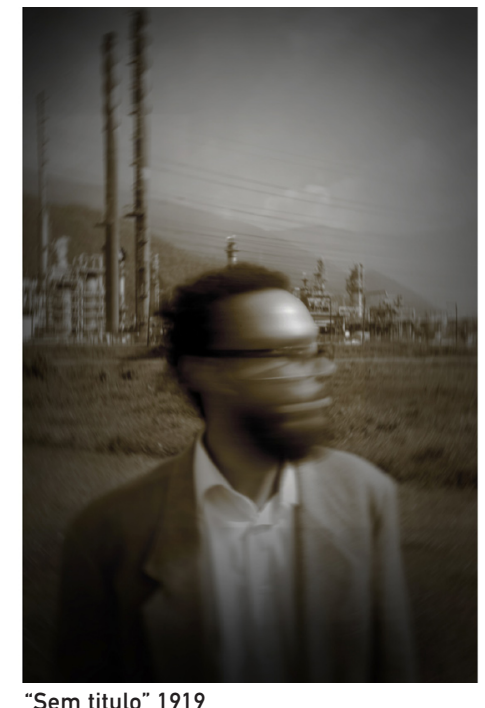

“Sem titulo" 1919

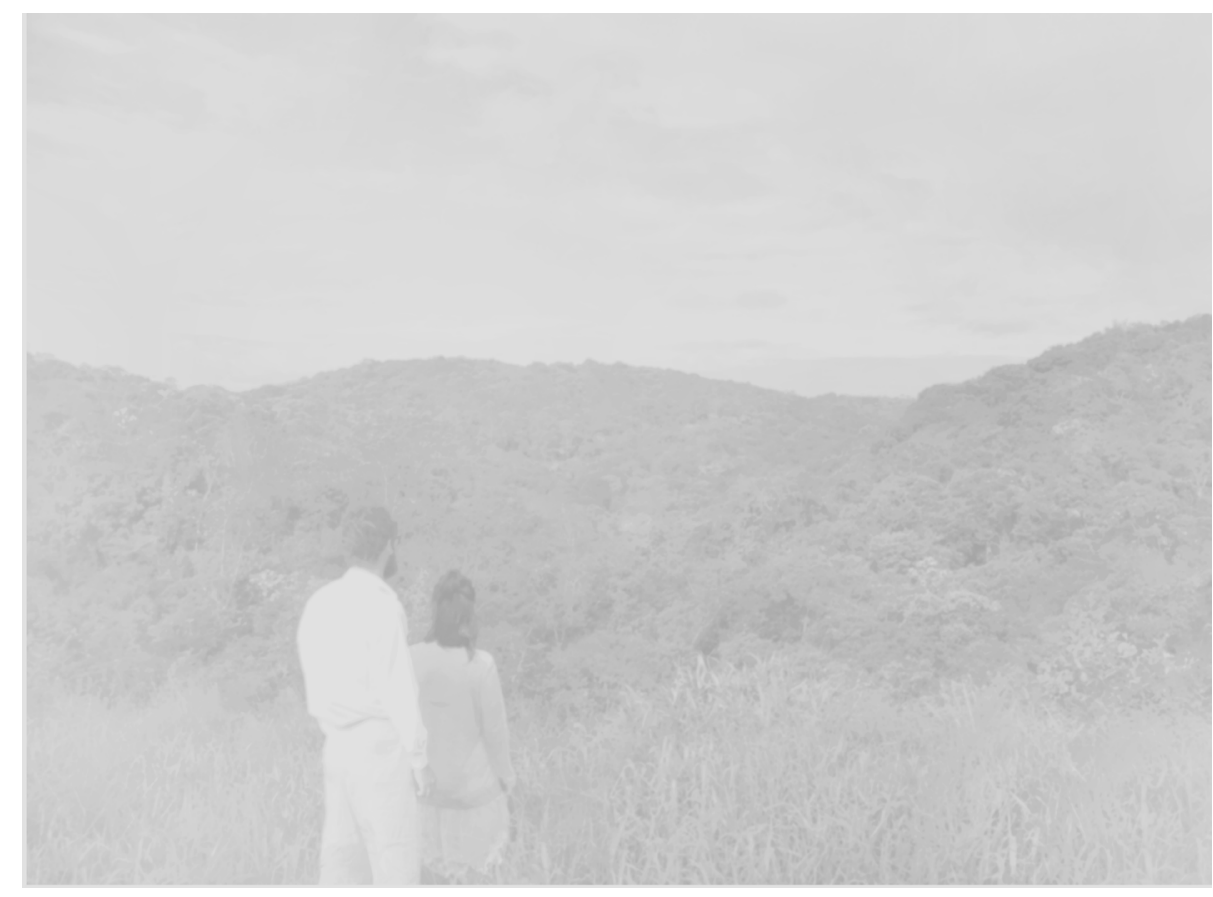

“Paisagem Partida” 1919 

Em diversas viagens a trabalho ou para pesquisas, realiza experimentos relacionados a toponímea indígena (estudo da origem do vocabulário tupi, relacionado ao acidente geográfico), realiza Pequeá, na Ilha de São Sebastião, quando pensava "em uma natureza diferente a que fala à camera ou aos olhos; diferente principalmente na medida em que em vez de um espaço impregnado de consciência pelos homens, surge um outro embrenhado pelo inconsciente" (Walter Benjamin "Kleine Geschichte der Fotografie" - Pequena História da Fotografia, Editora Relógio d’Água, Lisboa).

Em 1921 faz viagem ao litoral norte paulista com os amigos Letícia Queiroz, Boris Tatlov e Carvalho Andrade, onde realiza diversos experimentos com a fotografia.

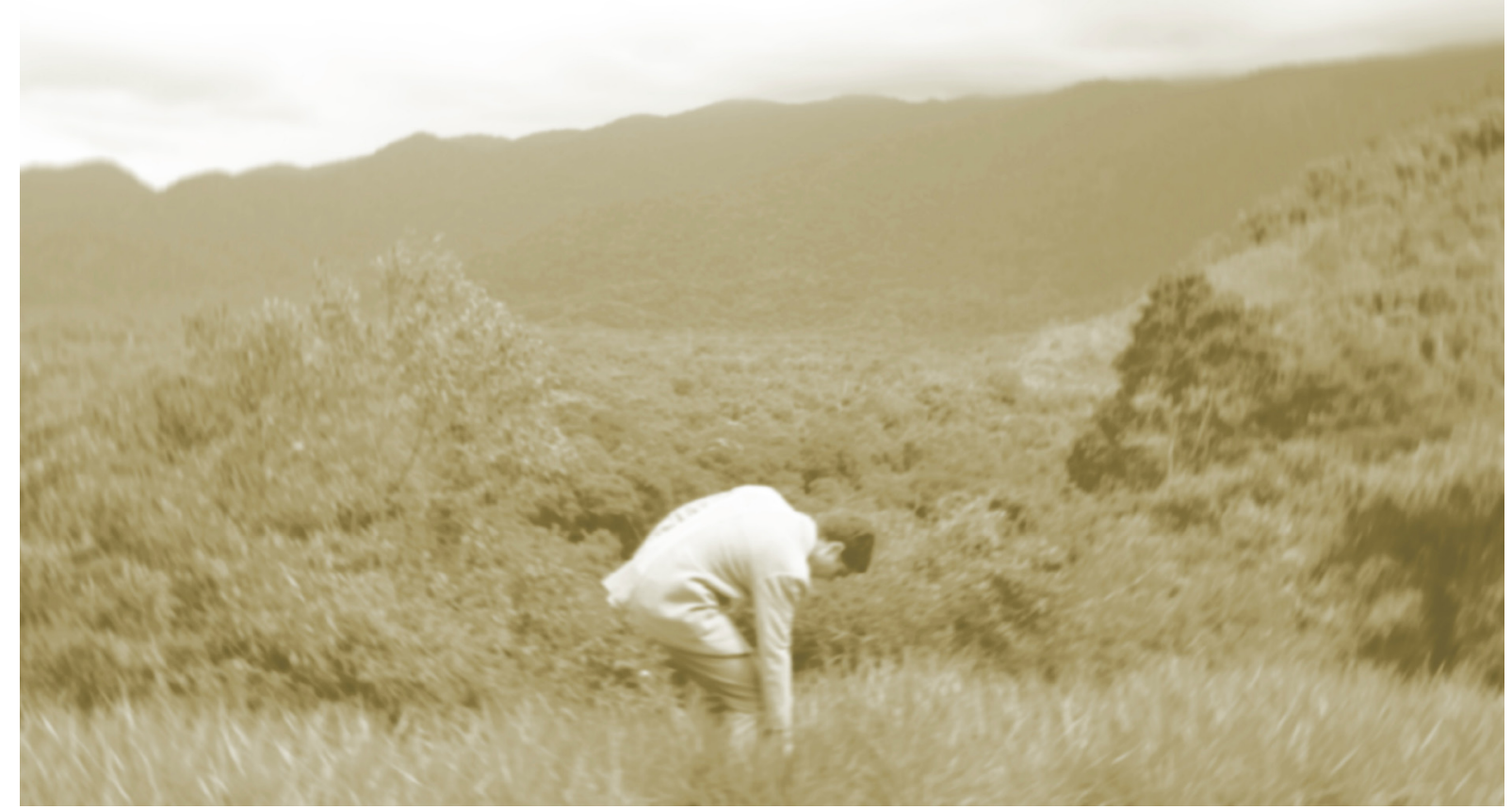

“Tiergarten” (trad. Jardim do animal) "Igoaguaçu” 1919 


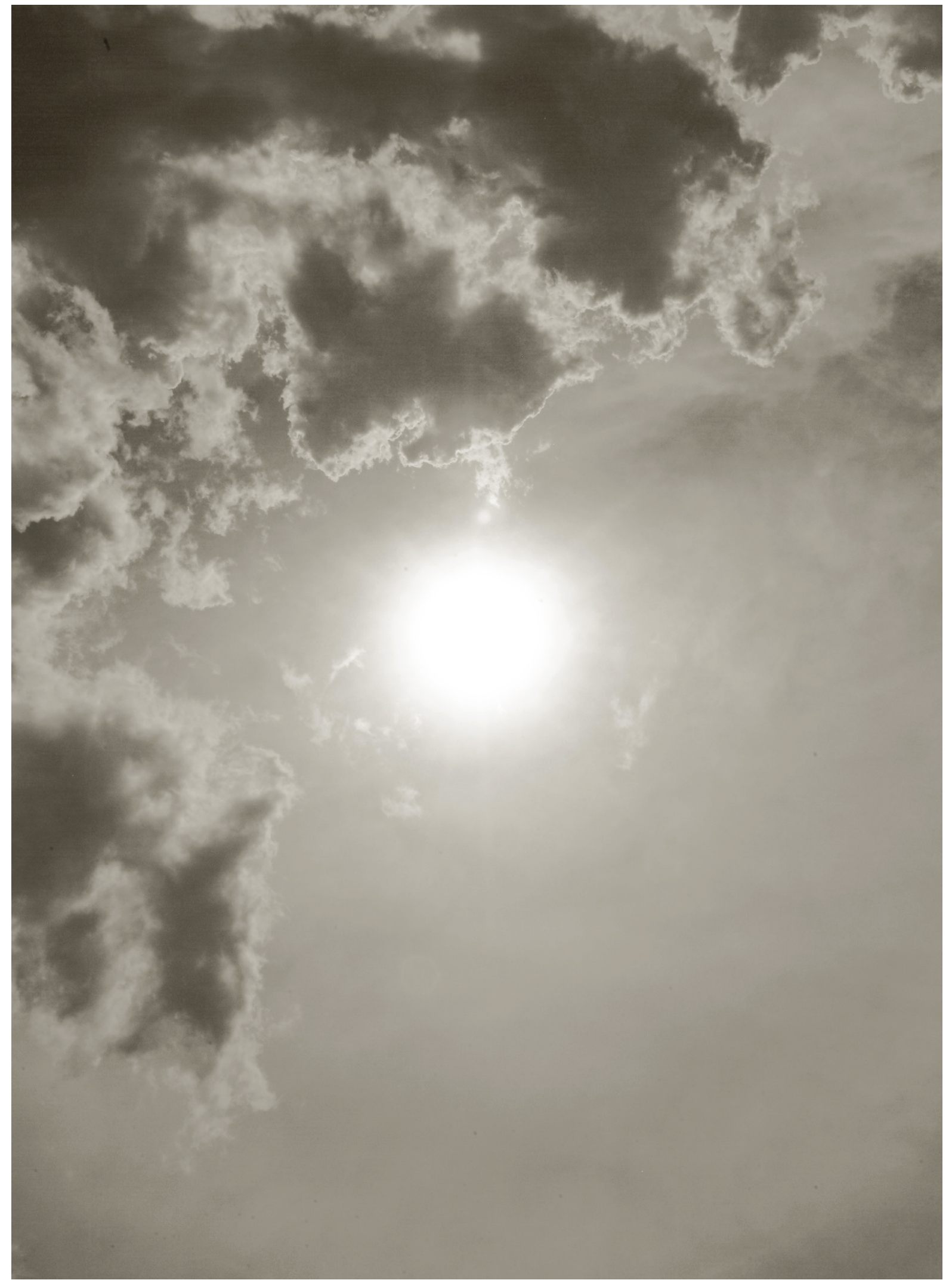




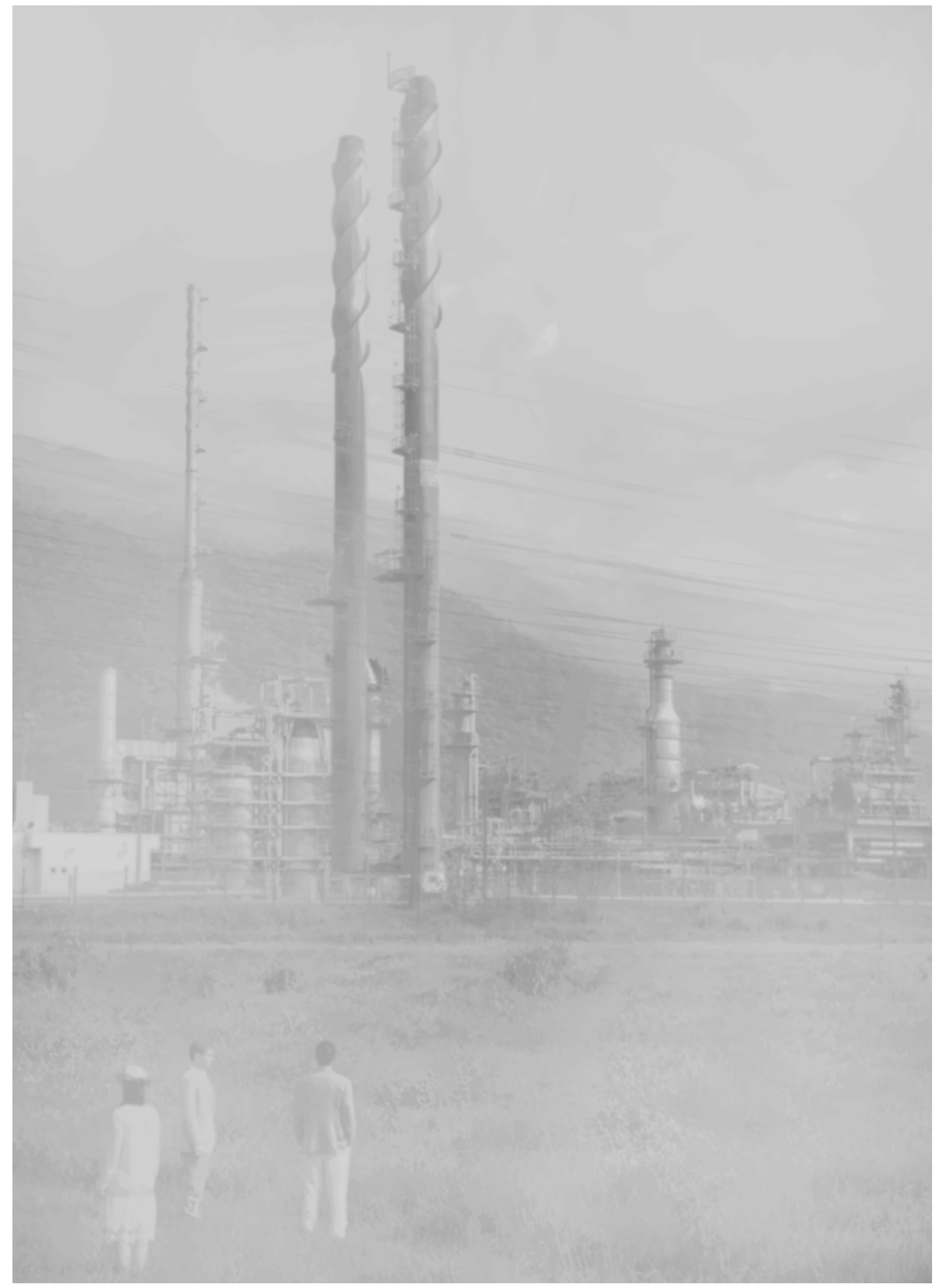




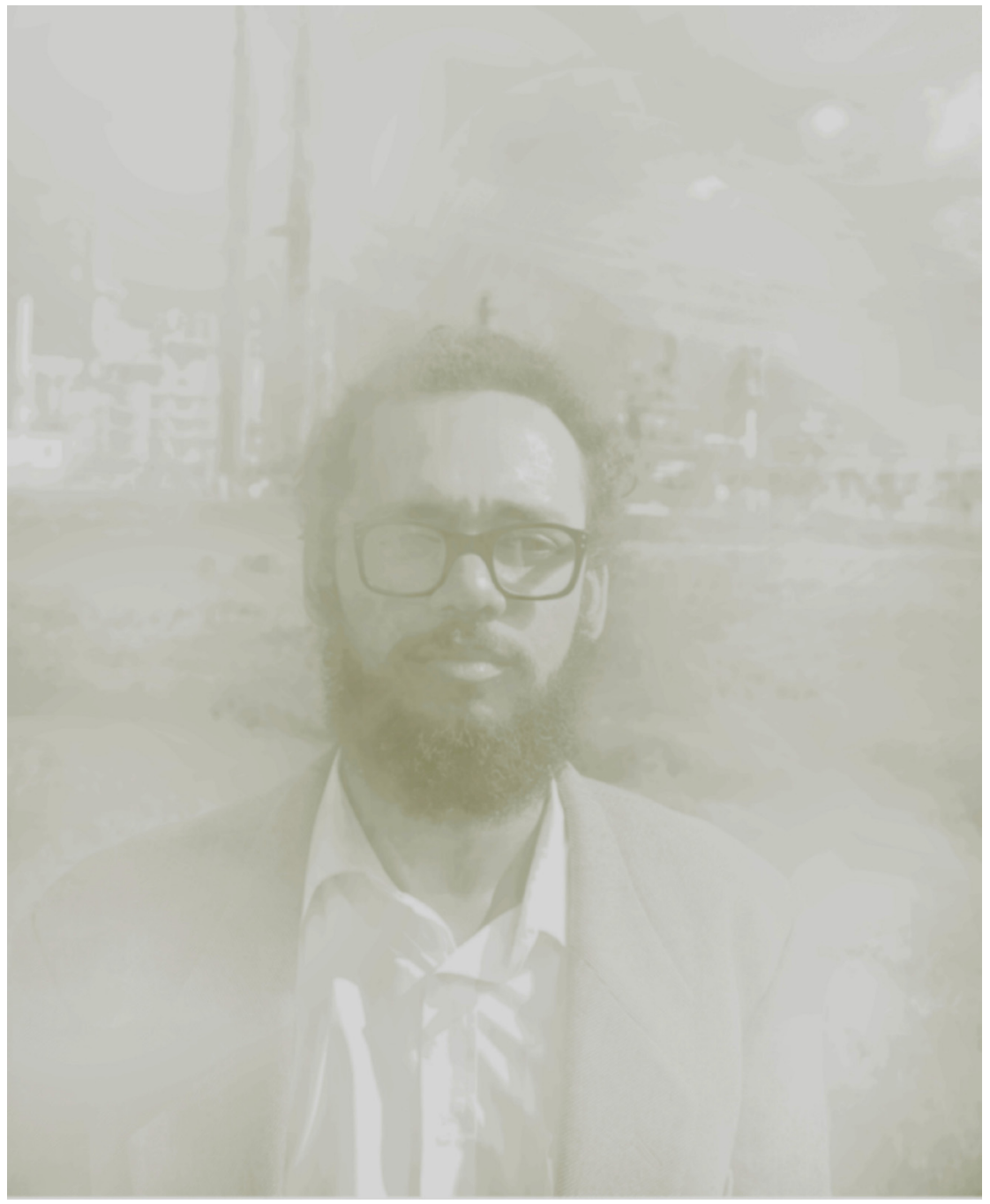




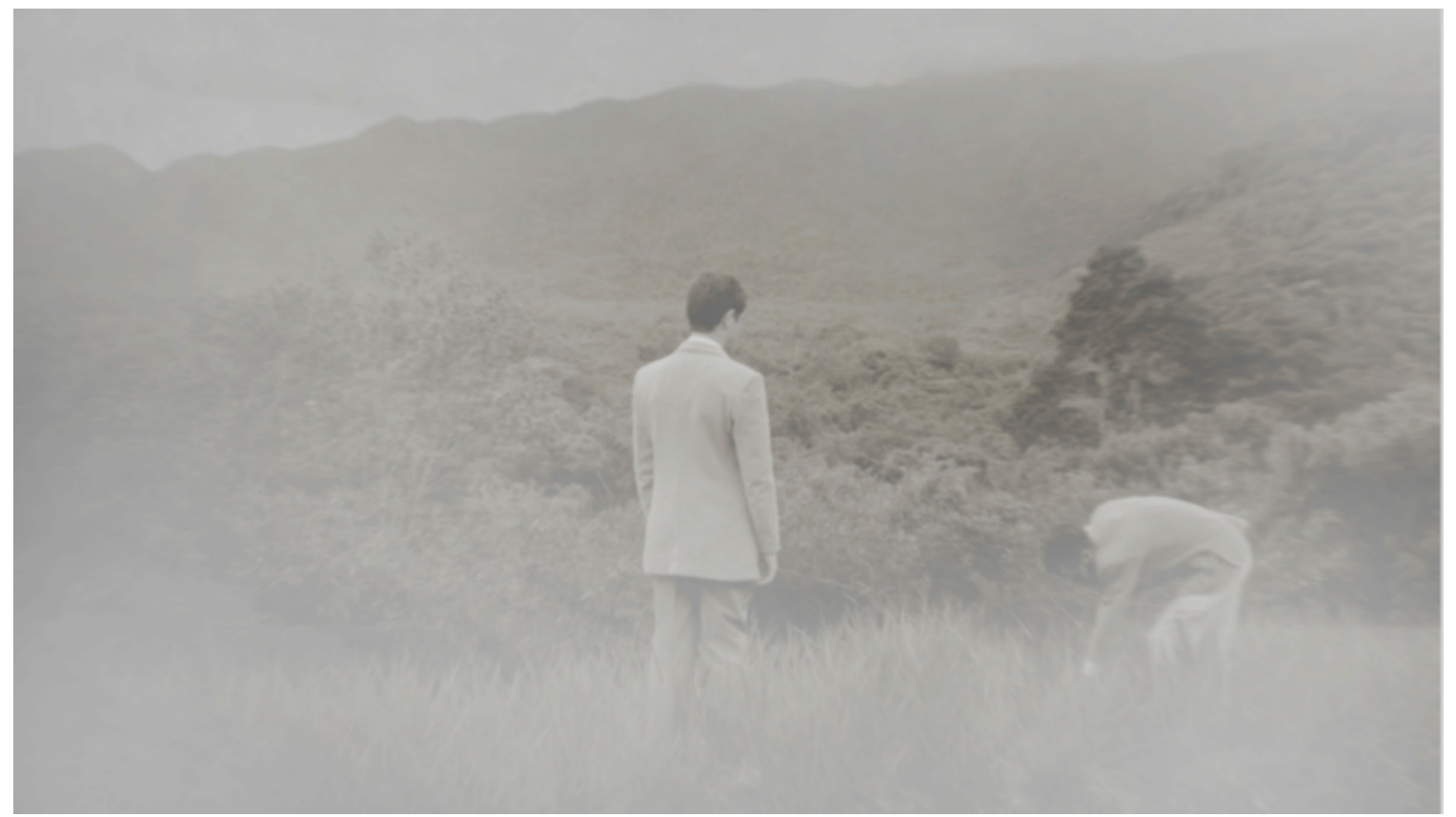




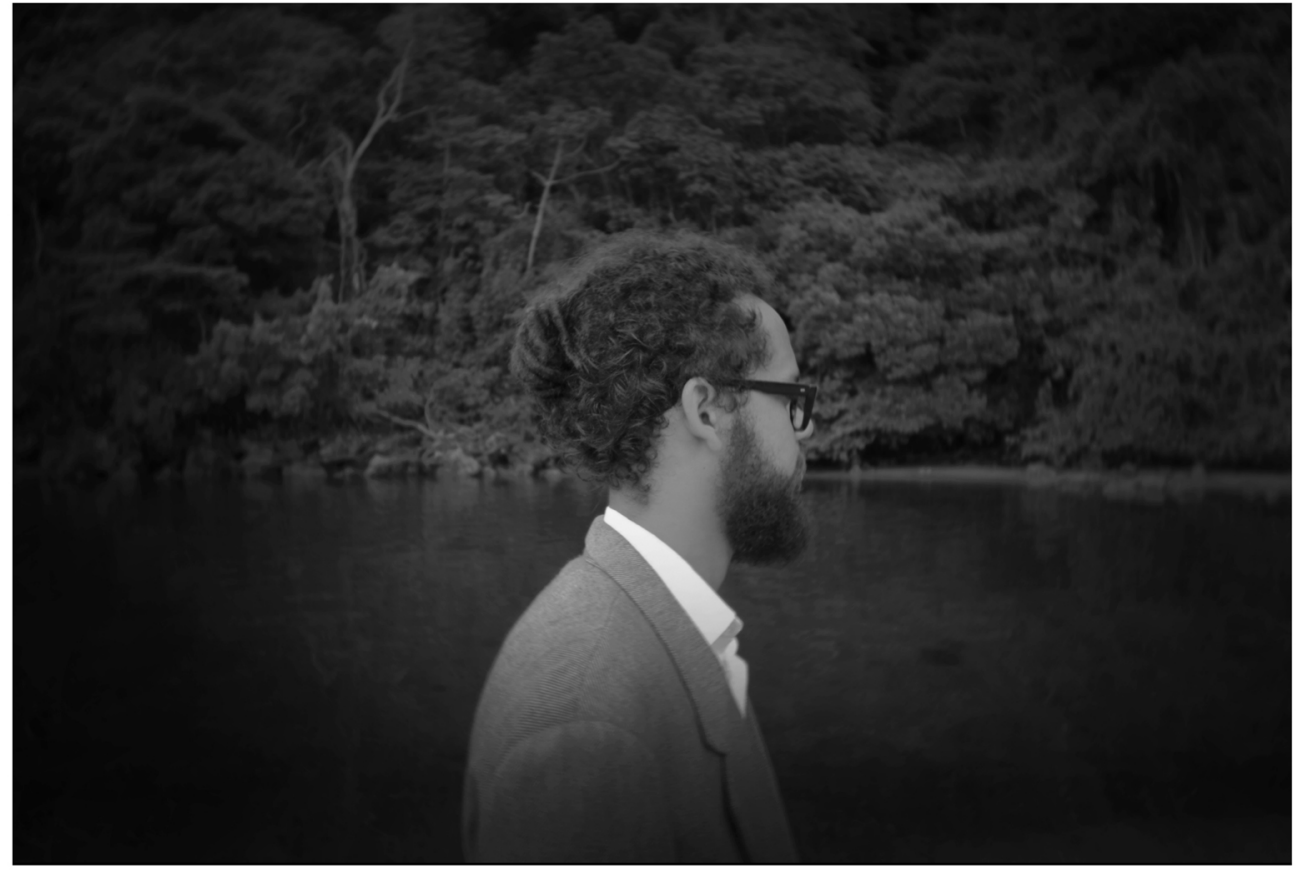




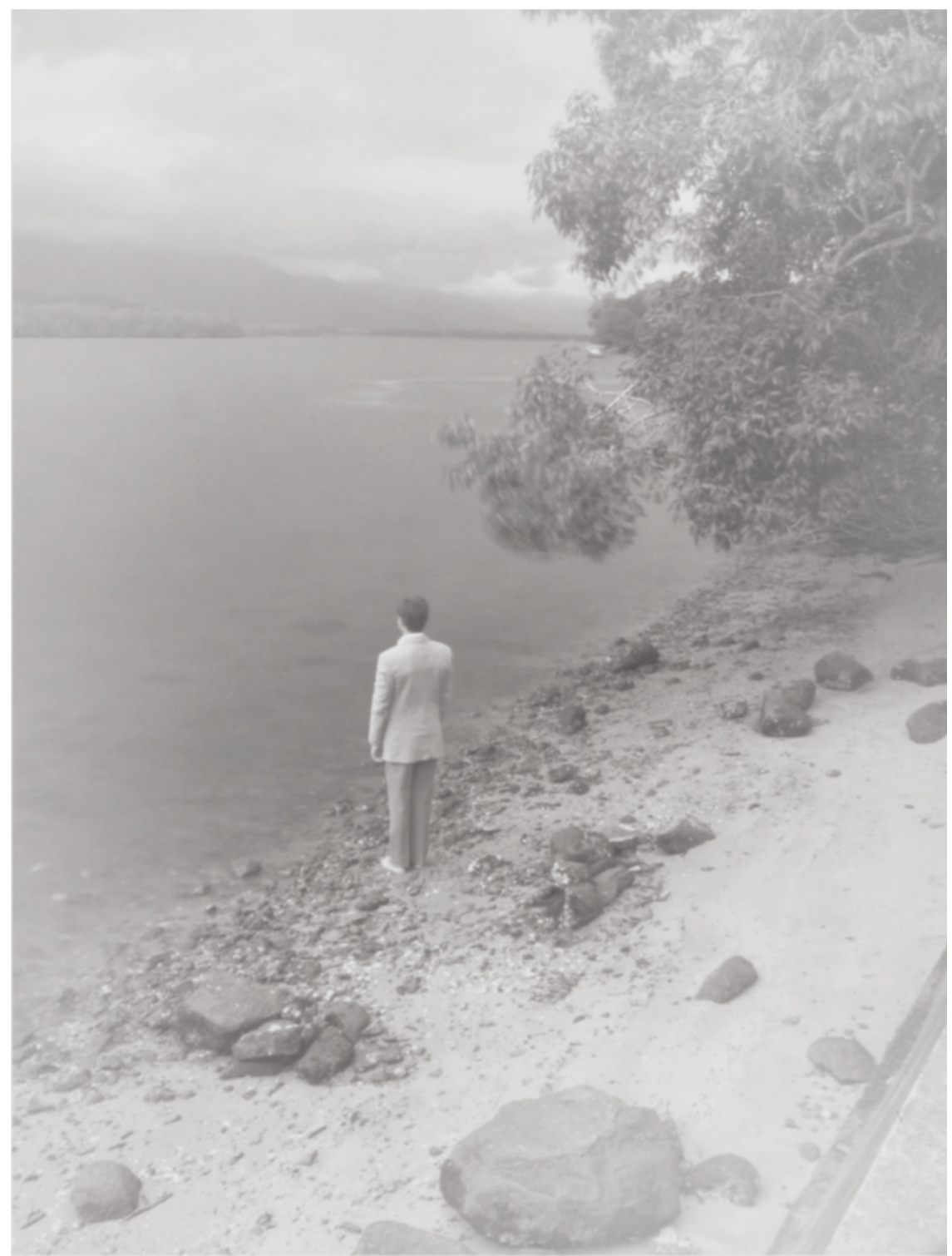




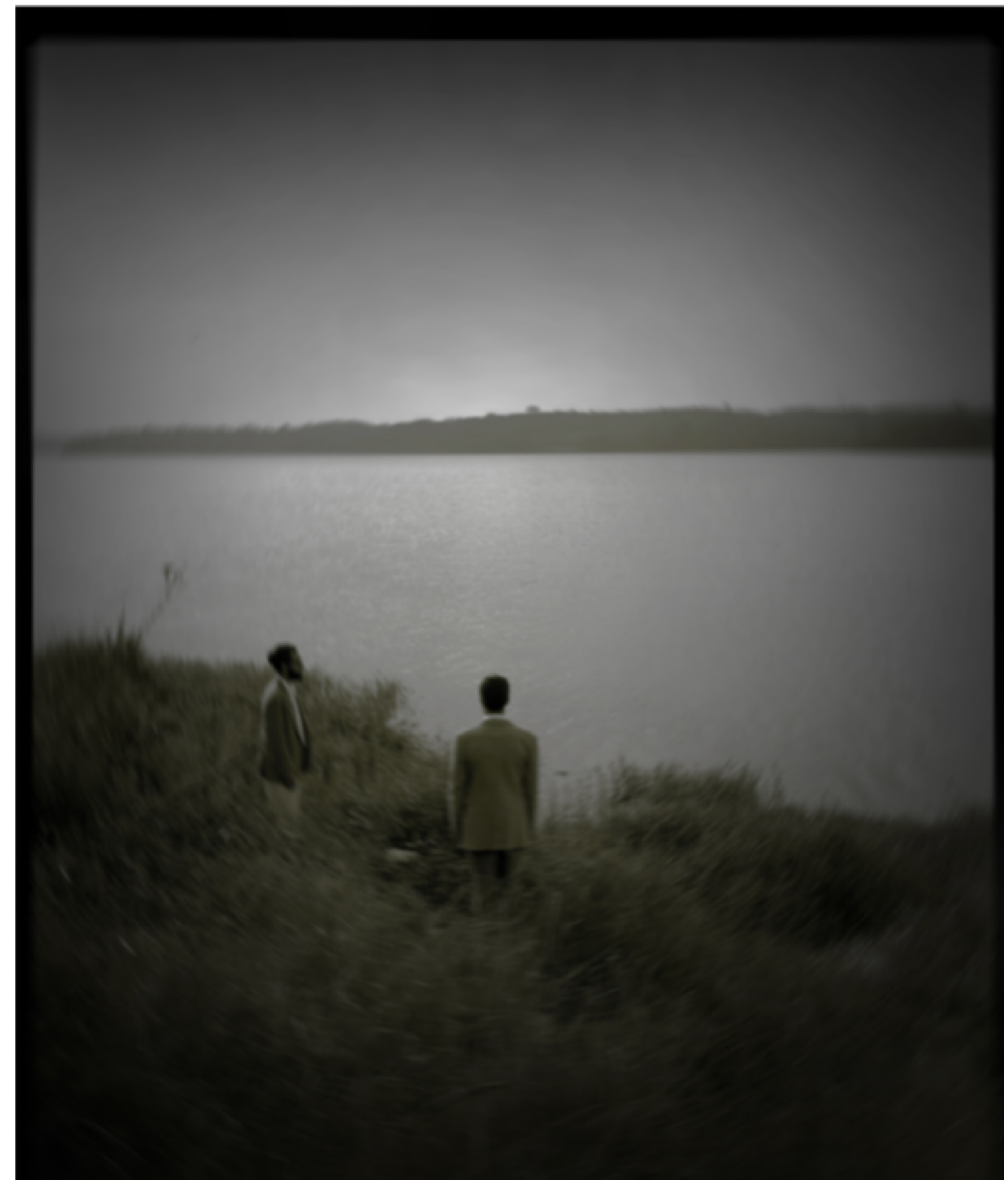




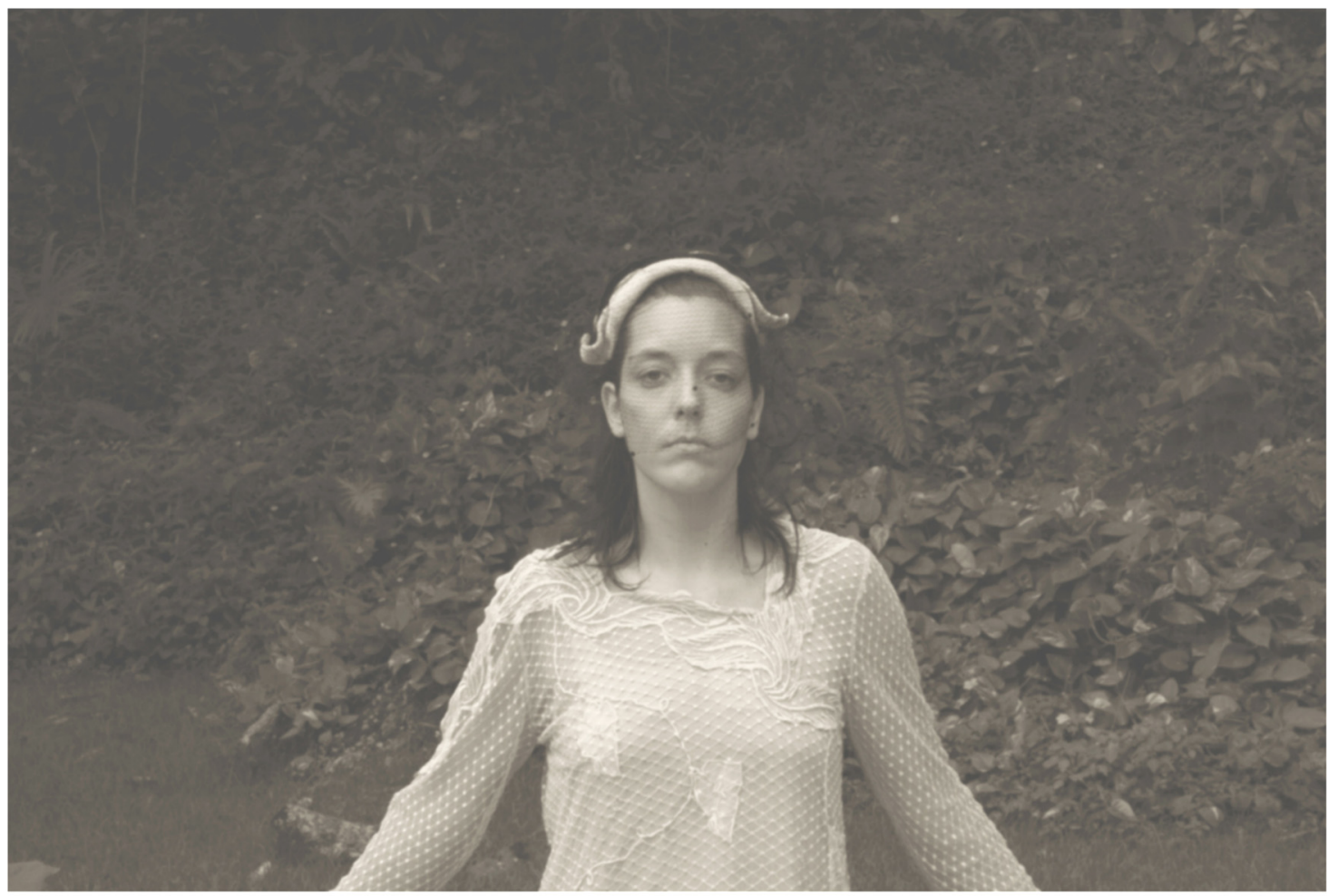




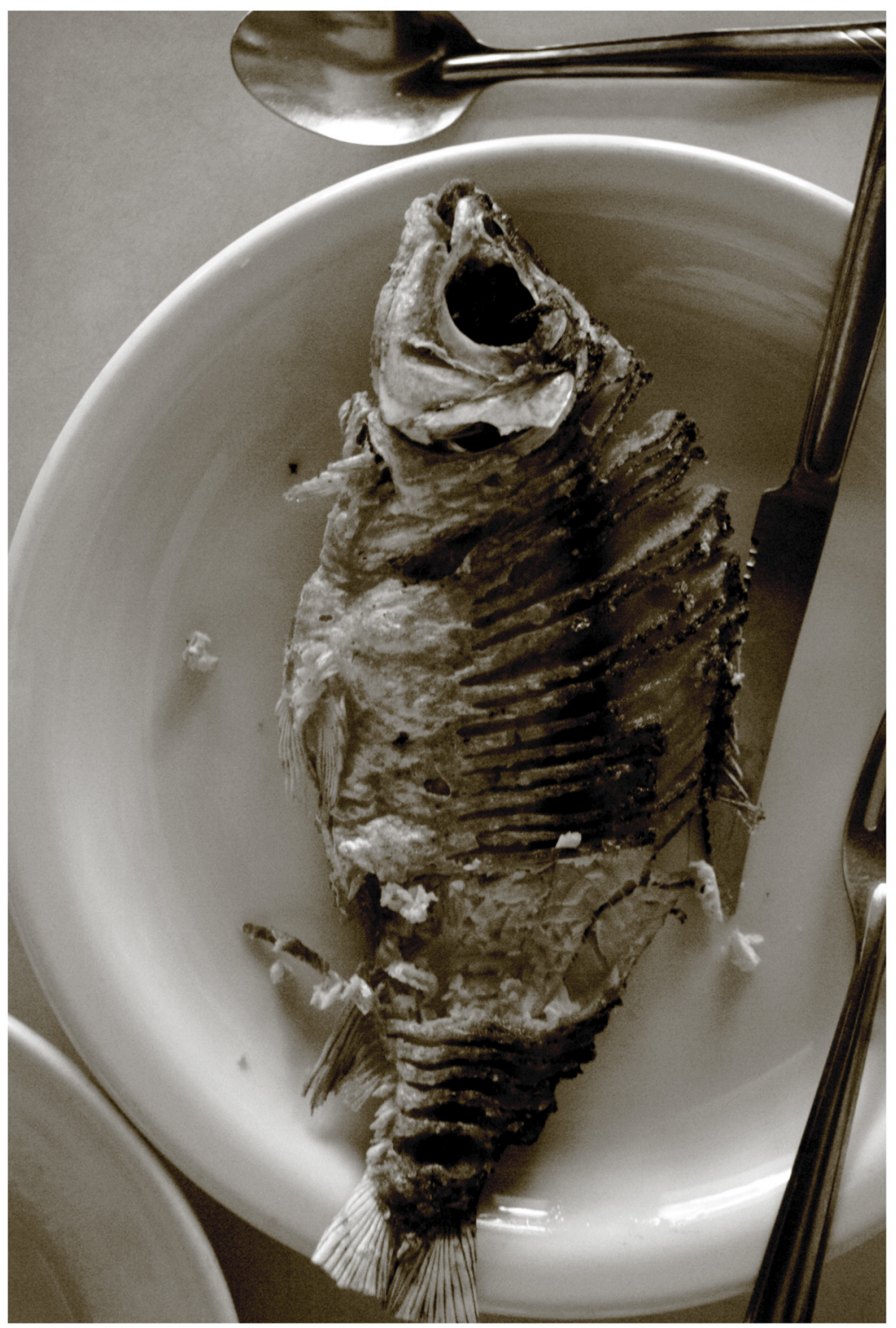




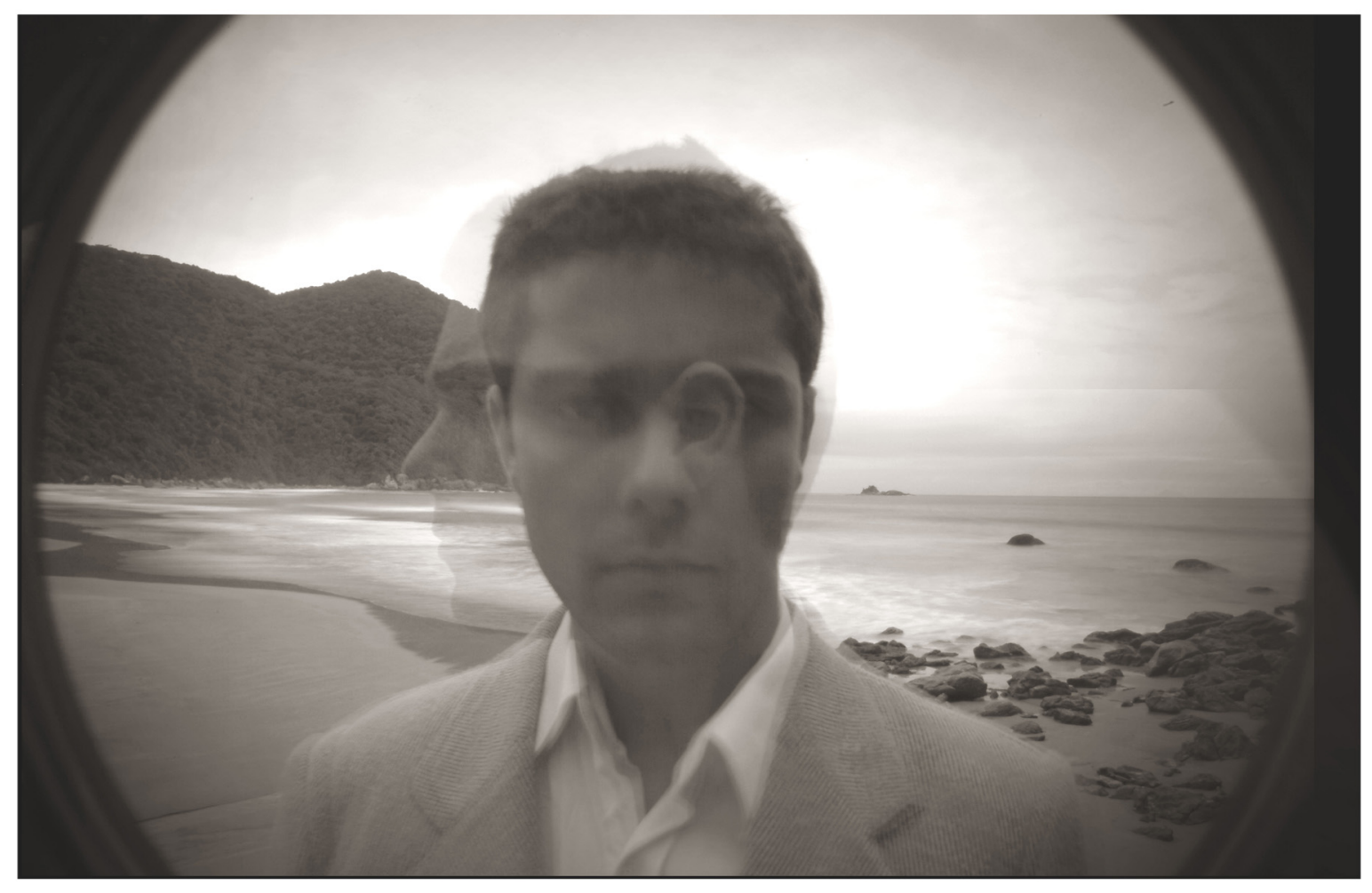




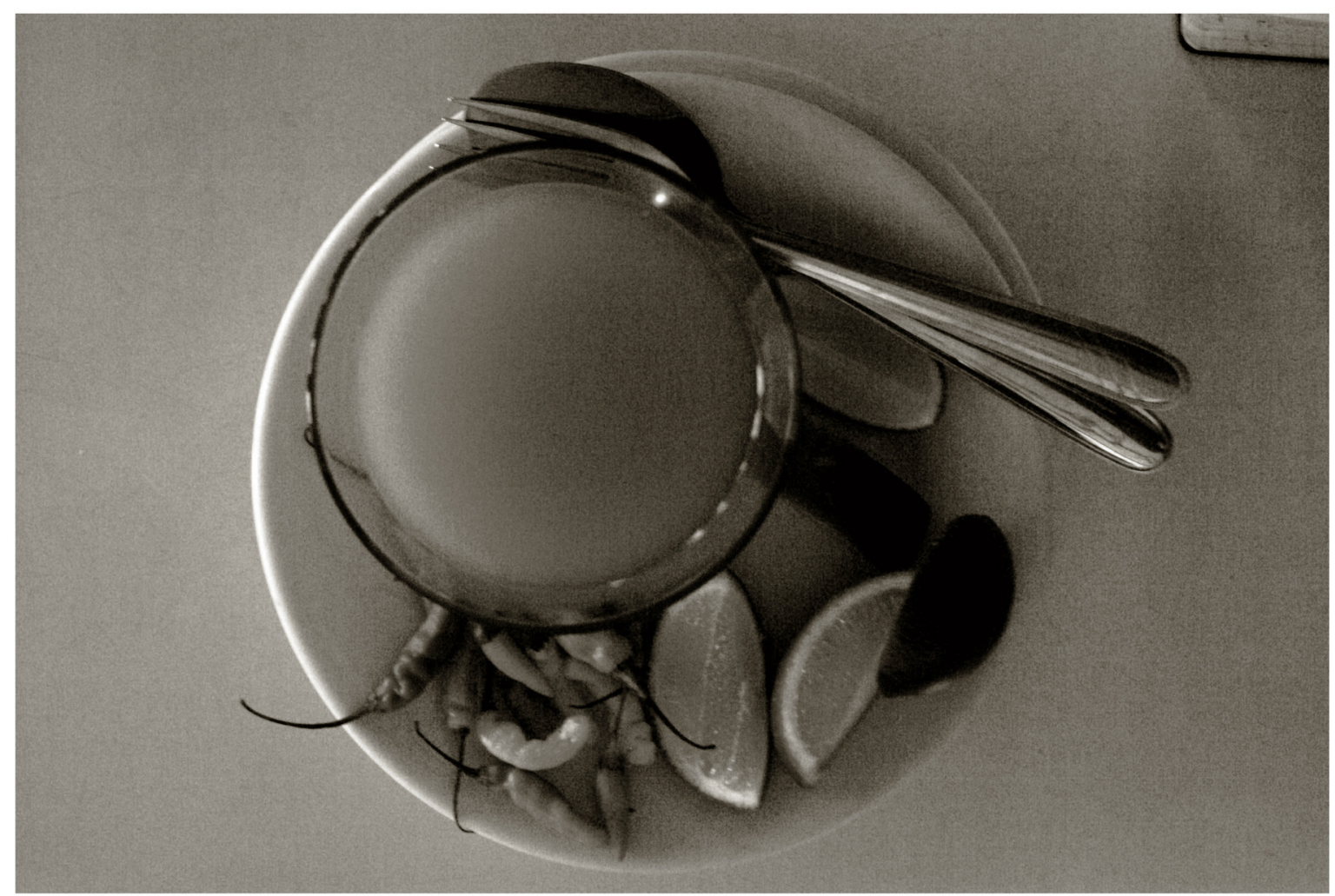

“Tacacá" (Trad. Caldo de mandioca) 1919 


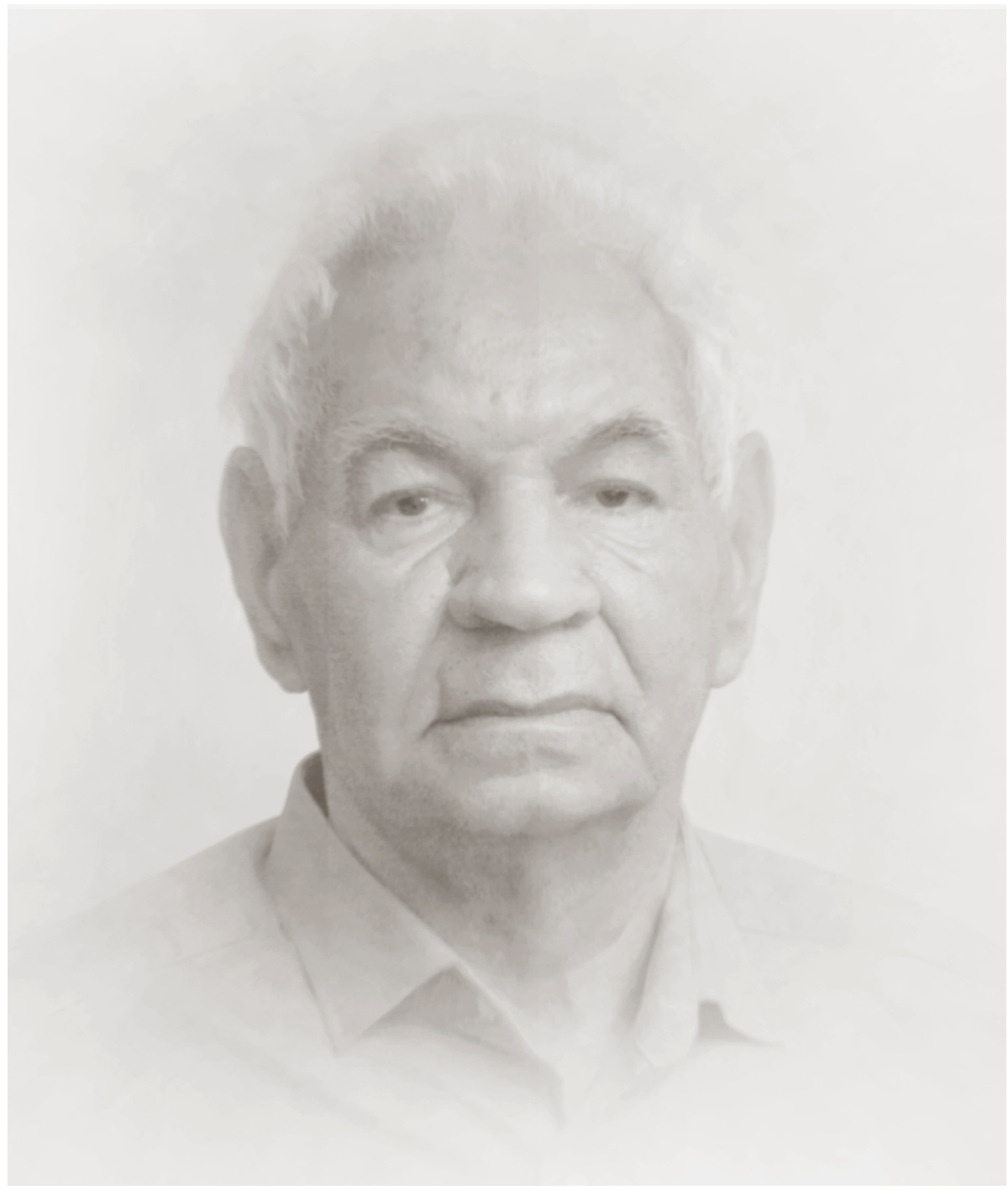




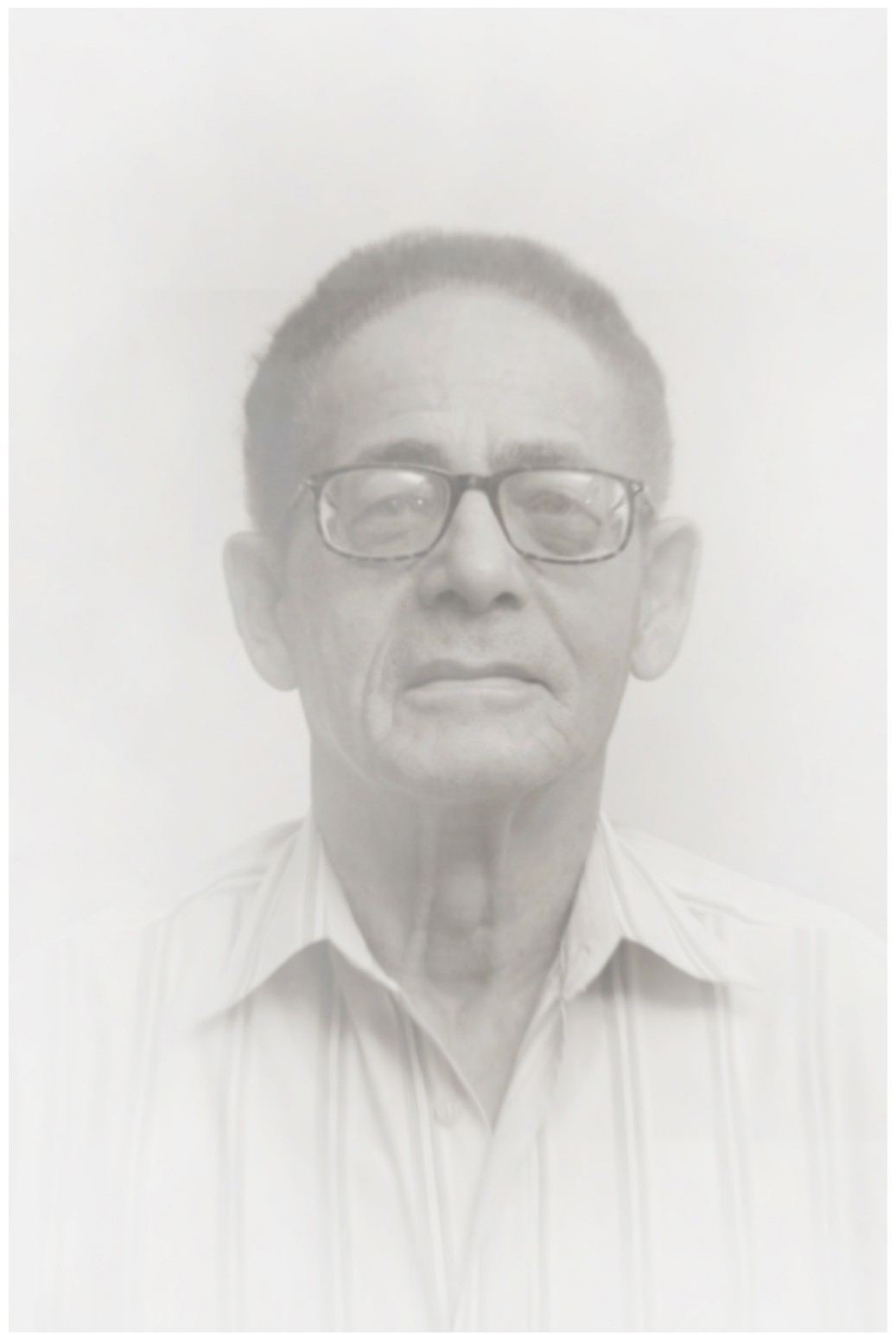




\section{EXPERIMENTO COM O FILME}

Com a ajuda do técnico italiano em filmagens, Luca Bambozzi, realiza o experimento com filme: TOBAYARA "16mm 1min" (c,Toabai - yara, o indivíduo fronteiro, aquele que está em frente, o vizinho de face. Teodoro Sampaio, O Tupi na Geografia Nacional, Brasiliana pag 331) acerca da idéia de romance alemão: O Vizinho (Der Nachbar), seguindo a idéia: "uma das funções revolucionárias do cinema será a de tornar reconhecíveis como idênticos os aproveitamentos artístico e científico da fotografia até agora divergentes na maioria dos casos. Isto porque o cinema, através de grandes planos, da exploração de ambientes banais com uma direção genial da objetiva, aumenta a compreensão das imposições que regem nossa existência e consegue assegurar-nos a um campo de ação imenso e inusitado. Chegou o cinema e fez explodir este mundo de prisões com dinamite de décimos de segundo, de forma tal que agora viajamos calma e aventurosamente por entre os destroços espalhados." (Walter Benjamin, A Obra de Arte na Era de sua Reprodutividade Técnica, pag 103-104 Editora Relógio d'Água, Lisboa).

O material para o filme era de bitola $16 \mathrm{~mm}$, mas curiosamente filmado em 24 quadros por segundo (na época eram mais comuns as filmagens em 18 quadros). Me parece que a camera apresentava problemas de entrada de luz (ou o carretel com o filme virgem foi exposto de forma indevida antes mesmo de ser rodado) pois o filme parece ter manchas de luz que entram e saem com certa freqüência. Eram carretéis fechados que podiam ser carregados mesmo a luz do dia, sem necessidade de sacos pretos. De todo modo trata-se de um material raro, feito com camera sofisticada para o período.

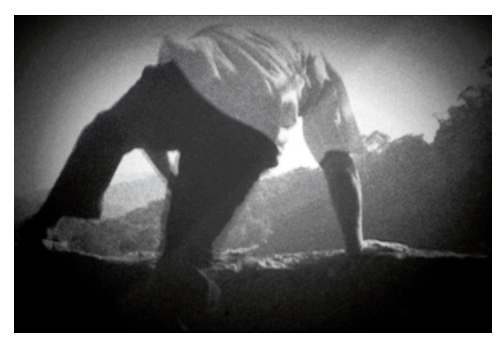




\section{ENCONTRO COM MARC FERREZ}

Em março de 1922, após o carnaval, Joaquim Reis decide viajar ao Rio de Janeiro a procura do fotógrafo Marc Ferrez. Um de seus professores na escola técnica de Berlim, Hans Klopp, havia conhecido Marc Ferrez em uma exposição universal em Paris, e sugeriu a Joaquim Reis que procurasse Marc Ferrez no Rio de Janeiro. Marc Ferrez já estava muito doente, numa fase menos ativa na fotografia e sim mais reflexiva. Joaquim Reis permanece alguns dias numa pensão muito próxima à residência de Marc Ferrez, e tem alguns encontros para conversar sobre fotografia.

Joaquim Reis mostra à Marc Ferrez a imagem YPORANGA realizada com amigos em Bertioga, a fim de discutir sobre a necessidade de fazer uma longa exposição mesmo ao ar livre. Os filmes tinham baixa sensibilidade. Essa necessidade fazia desejável o fotógrafo colocar-se num lugar tão solitário possível, em que nada perturbasse um conjunto sossegado. "A síntese de expressão obtida através da longa quietude do modelo e o motivo principal que faz com que estas - para além da sua simplicidade da qualidade das imagens ser tão boa como a de desenhos ou pinturas - exerçam o efeito mais profundo e duradouro em que se observa do que as fotografias mais recentes. O procedimento em si motivava os modelos a viver intrinsecamente o momento e não a inspirar-se nele; durante o longo tempo que estas fotografias demoravam, eles cresciam de certo modo na própria imagem, contribuindo desse modo, para o mais decisivo contraste com as aparências de uma fotografia de monumento". (Walter Benjamin, "Kleine Geschichte der Fotografie" - Pequena História da Fotografia, pag 121, Editora Relógio d’Água, Lisboa). 

Marc Ferrez argumentava sobre esse "ambiente alterado" e dizia que um fotógrafo deveria estar a altura de seu instrumento de trabalho (PELA PRIMEIRA, E DURANTE LONGO TEMPO, PELA ÚLTIMA VEZ). Ele falava sobre a "condução globalizante da luz" que devido aos longos tempos de exposição, confere a estas primeiras fotografias a sua grandeza.

Dizia que entre os contemporâneos dessa invenção, se verificava a impressão geral, anteriormente nunca atingida, magnífica, que nada perturbava a tranqüilidade das pessoas, uma trama peculiar de espaço e tempo; aparência única de uma distância, por muito perto que possa estar.

Naquele instante, Marc Ferrez, com muita calma, tentava transmitir a Joaquim Reis o pensamento relacionado ao condicionamento técnico da aparência da aura.

Joaquim Reis dizia que sua questão consistia em sublinhar a "aproximação" entre as pessoas e os objetos, tendência tão apaixonante como a de querer ultrapassar o único, através de sua reprodução. (trechos de: Walter Benjamin "Kleine Geschichte der Fotografie", Pequena Historia da Fotografia, pag 125,127,129,130 e 131, editora Relógio d'Água, Lisboa).

Marc Ferrez morre, na noite de 12 de janeiro de 1923. 


\section{ANTES DO PHOTOSHOP}

Em 1929, Joaquim Reis reencontra Boris Tatlov, que havia passado por Berlim no caminho de volta a Moscou.

Conhece através de Boris, um amigo arquiteto que havia costruído uma casa na Rua Santa Cruz no bairro da Vila Mariana em São Paulo. Joaquim Reis fotografa a casa para o arquiteto Gregori Warchavchik. Acontecia naquele momento, um rompimento na arquitetura brasileira.

Atravéz de Boris e Gregori conhece Natasha Yeltsin com quem tem um romance.

Boris trazia consigo publicações que amigos de Berlim haviam enviado para Joaquim Reis. Atravéz dessas publica-

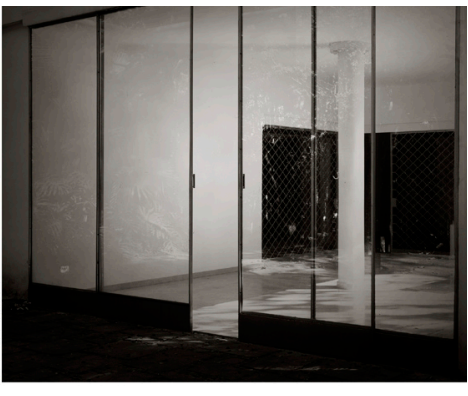

Casa Rua Santa Cruz 1929 ções, entra em contato com experimentos de colagem, fotografia e assemblage de diversos autores como: Raul Haussman, Hannah Hoech e Johannes Baader.

Joaquim Reis começa a observar que está muito próxima a tentação de simplesmente atribuir a decadência do sentido da arte a um fracasso dos contemporâneos, e contra isso, surge o reconhecimento do fato de, mais ou menos ao mesmo tempo, com a evolução das técnicas reprodutivas, se ter alterado a compreenção de grandes obras.

"Percebe que quanto mais se alastra a crise da ordem da sociedade atual, mais seus momentos isolados se enfrentam em antagonismos sem vida, mais a criação se torna um fetiche." (Walter Benjamin "Kleine Geschichte der Fotografie" - Pequena Historia da Fotografia, pag 131,132 e 133 - Editora Relógio d’Água, Lisboa).

Encontrei uma série de fotografias e experimentos datadas de 1929. Não encontrei mais nada, para onde Joaquim Reis foi e o que aconteceu com ele. 


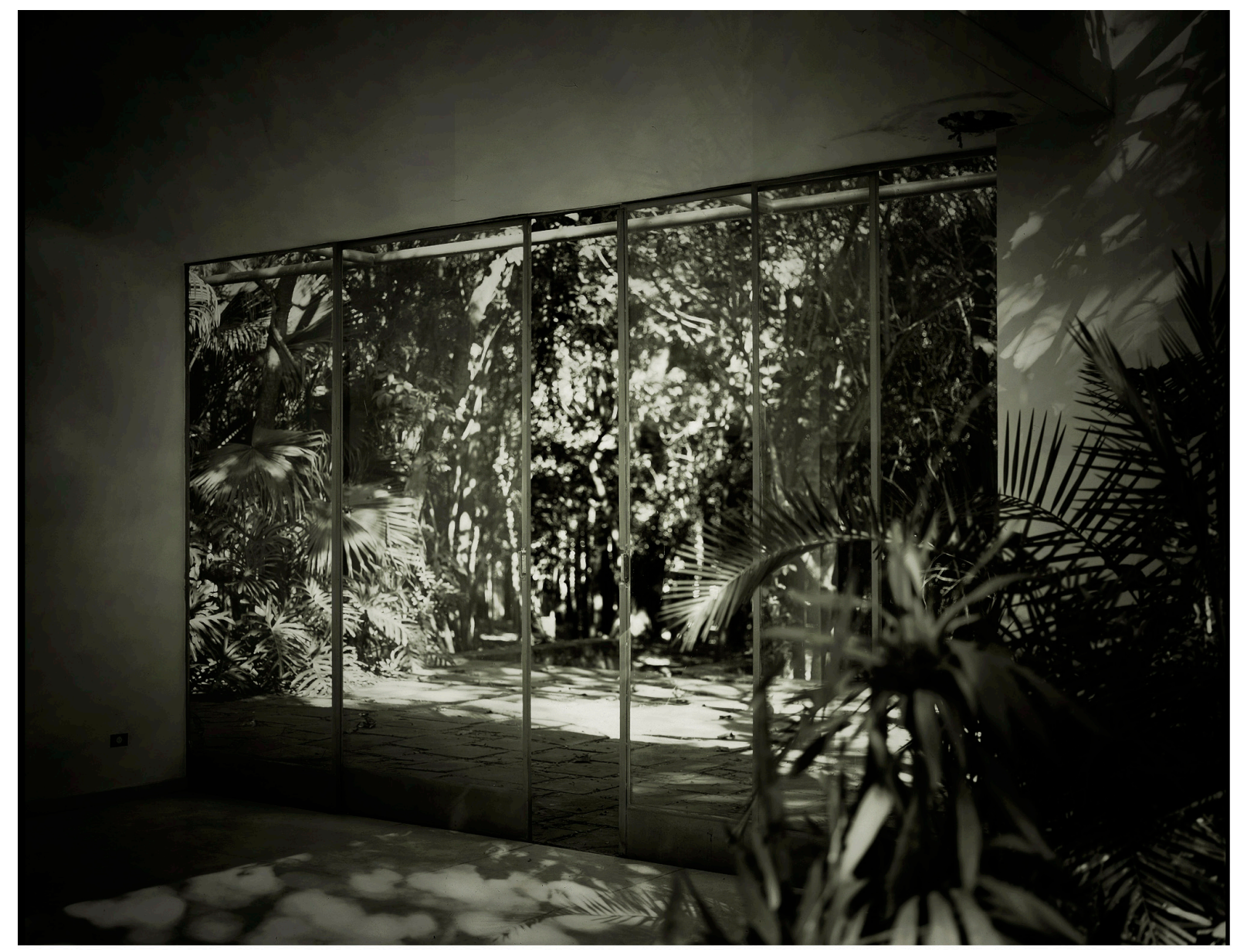



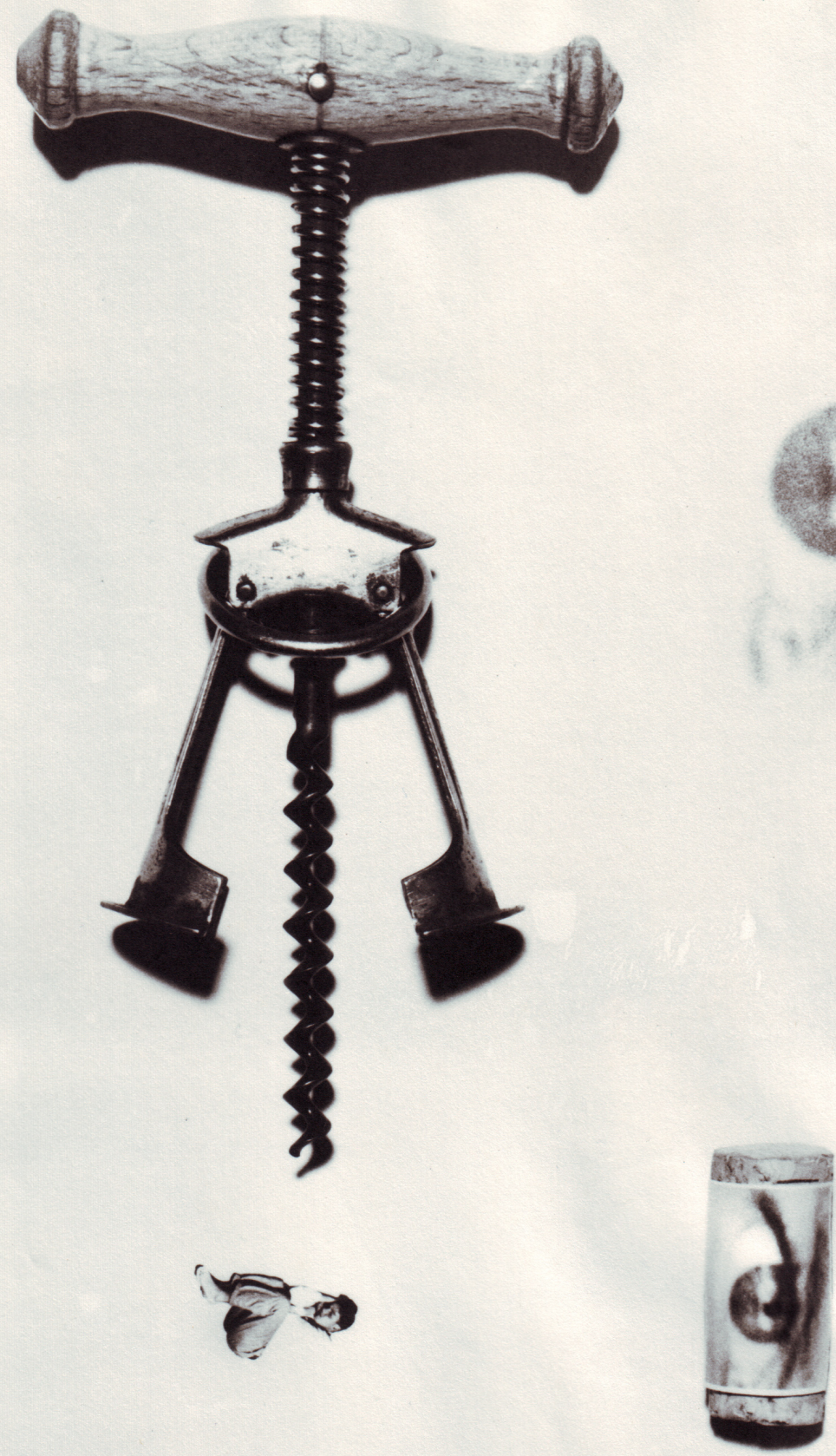


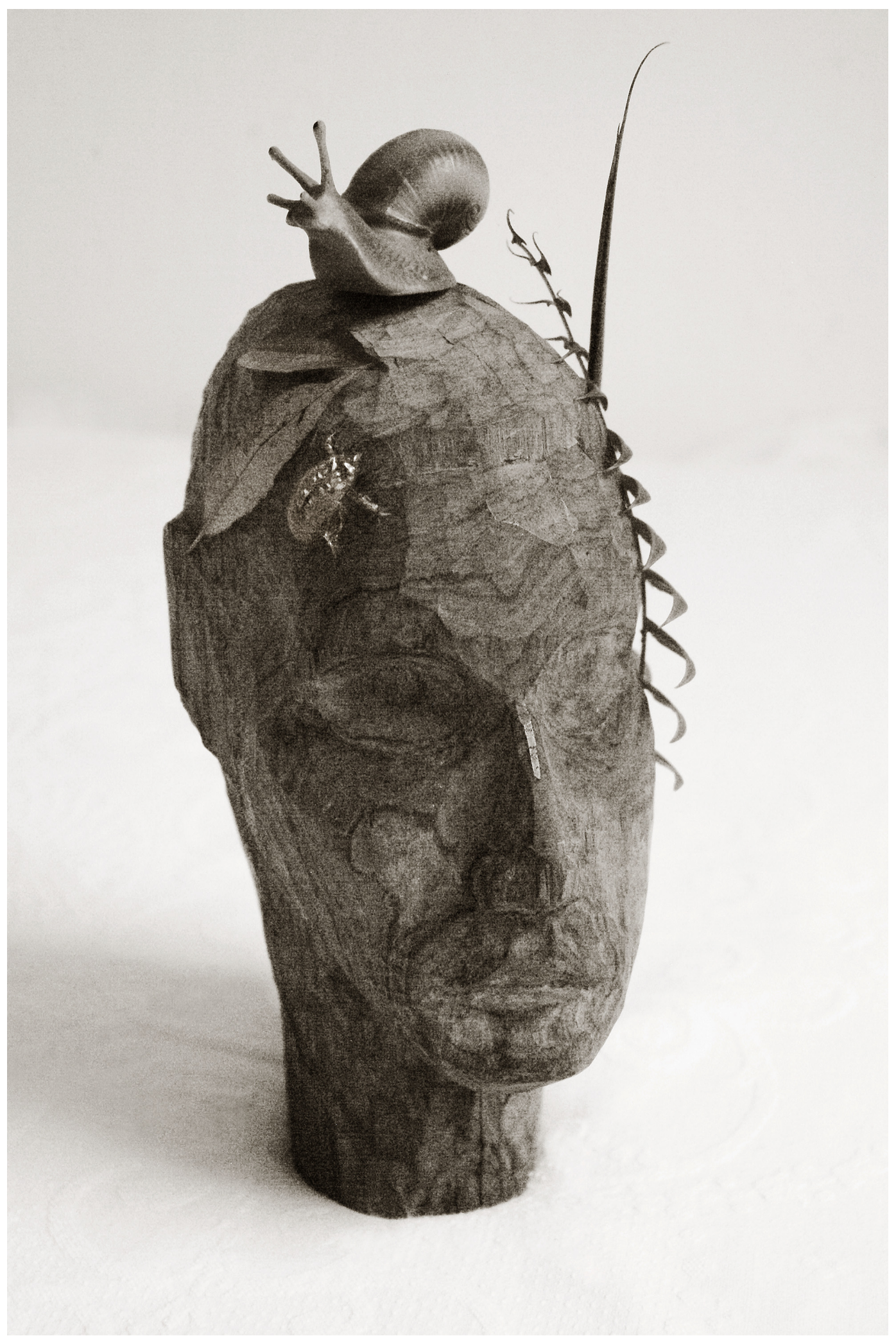




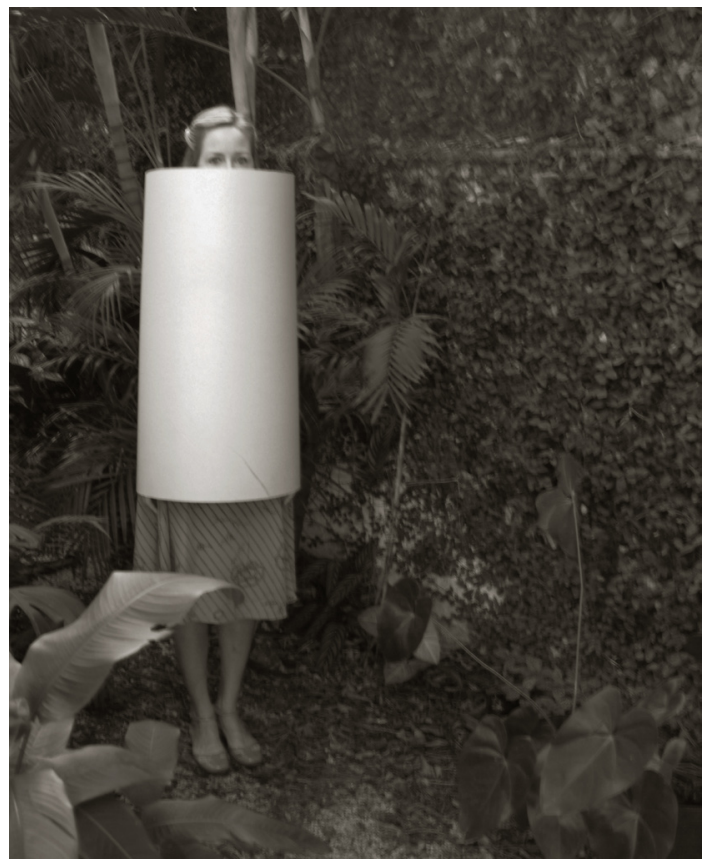




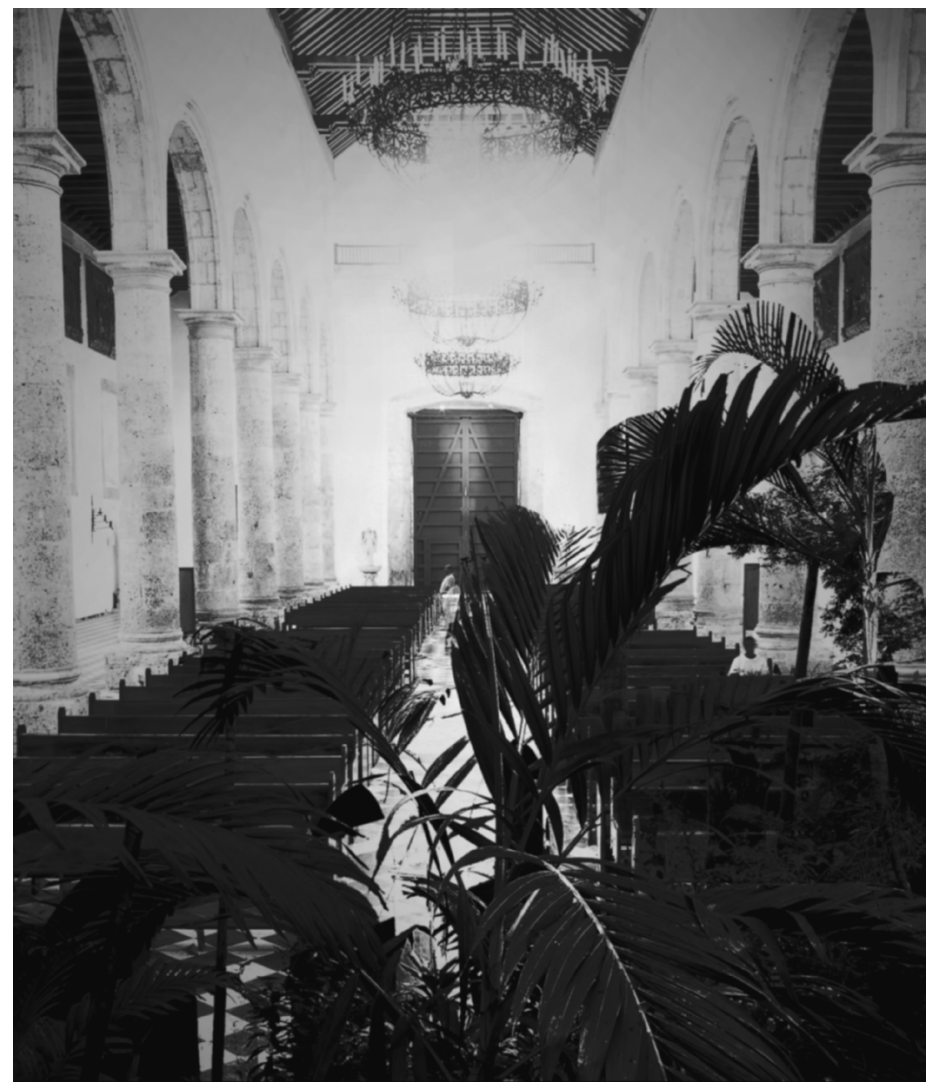




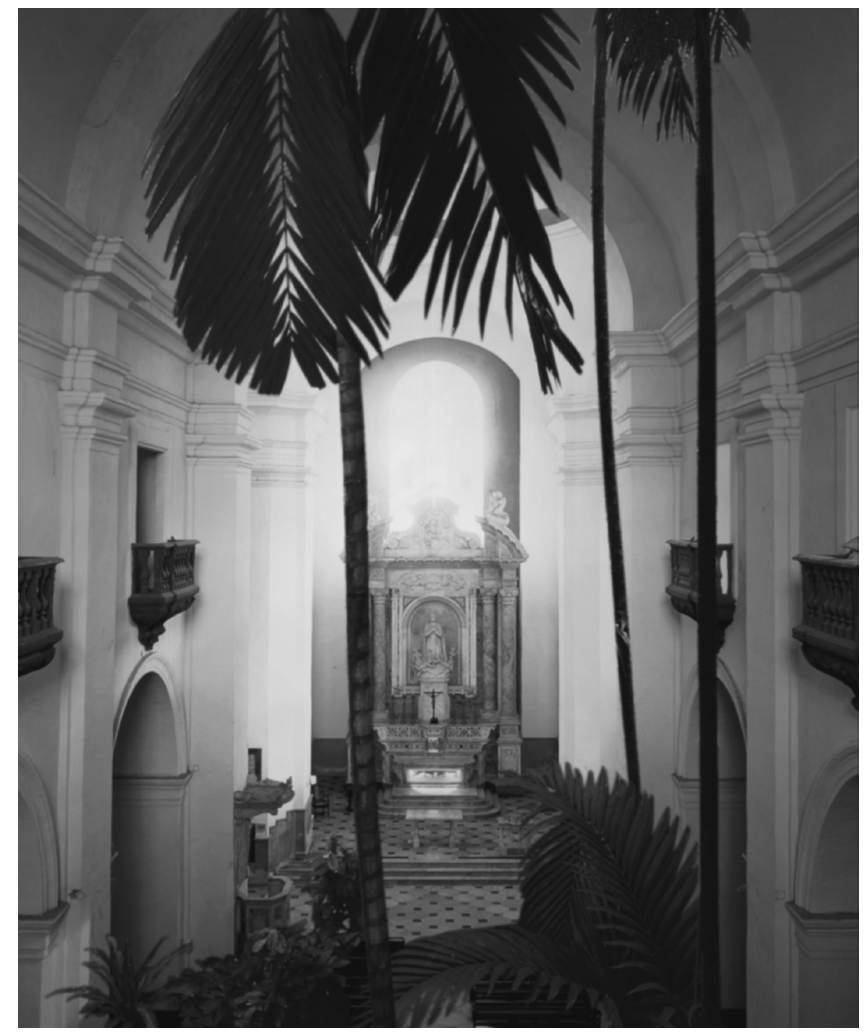








\section{SEM CONCLUSÃO}

Encontrar a obra de Joaquim Reis foi o melhor caminho para me aproximar dos pensamentos e dos processos de criação de um artista, que viveu num tempo em que a fotografia, tendo a possibilidade de ser um aparelho de reprodução, causou uma gama de reflexões, descritas principalmente no texto de Walter Benjamin, Pequena História da Fotografia.

Acho muito difícil concluir uma análise sobre uma obra de arte. Uma obra de arte vive da possibilidade de ser interpretada de diferentes maneiras, ser reinventada. Isso faz uma obra de arte ter sentido. Justamente foi isso o que me fascinou ao ter encontrado aquela caixa na Biblioteca Nacional do Rio de Janeiro. Investigar os novos campos da obra de Joaquim Reis. 
(DIA VIA) Passando pelas llhas da Madeira, Canarias e Cabo Verde, percebi que tinham uma formação rochosa muito árida e seca. Nessas ilhas não havia muita fonte de água, a vegetação era muito seca. Realizei alguns registros. Muito diferente disso encontrei, depois de atravessar o oceano uma formação de montanhas muito próxima ao litoral (Serra do Mar). Todo esse trecho tem como característica uma cordilheira de montanhas extremamente tropical um uma mata intensa, muita chuva, sol e cachoeiras infinitas. Na parada em Santos encontrei uma carta náutica do litoral do Rio de Janeiro, a llha de Santa Catarina.

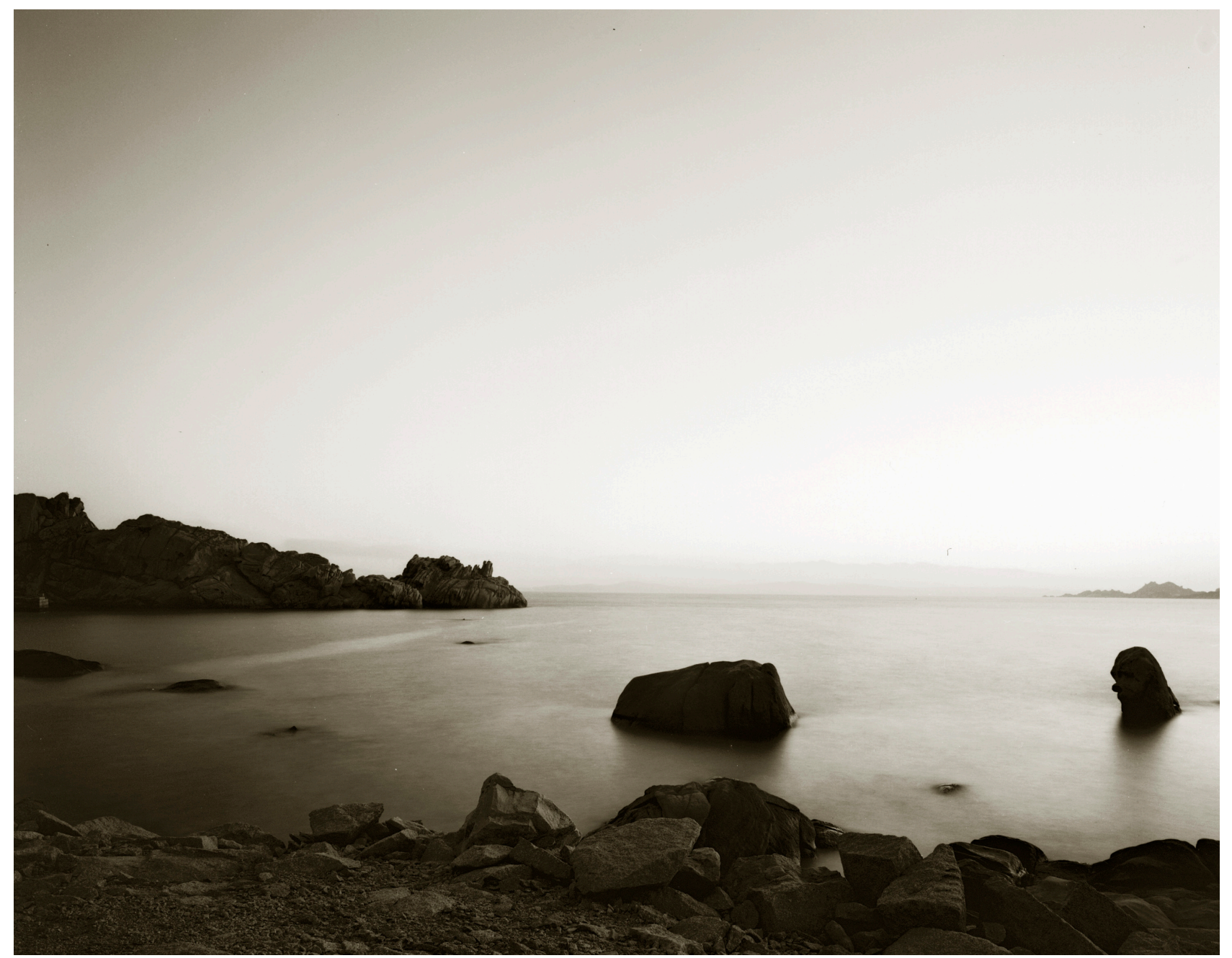




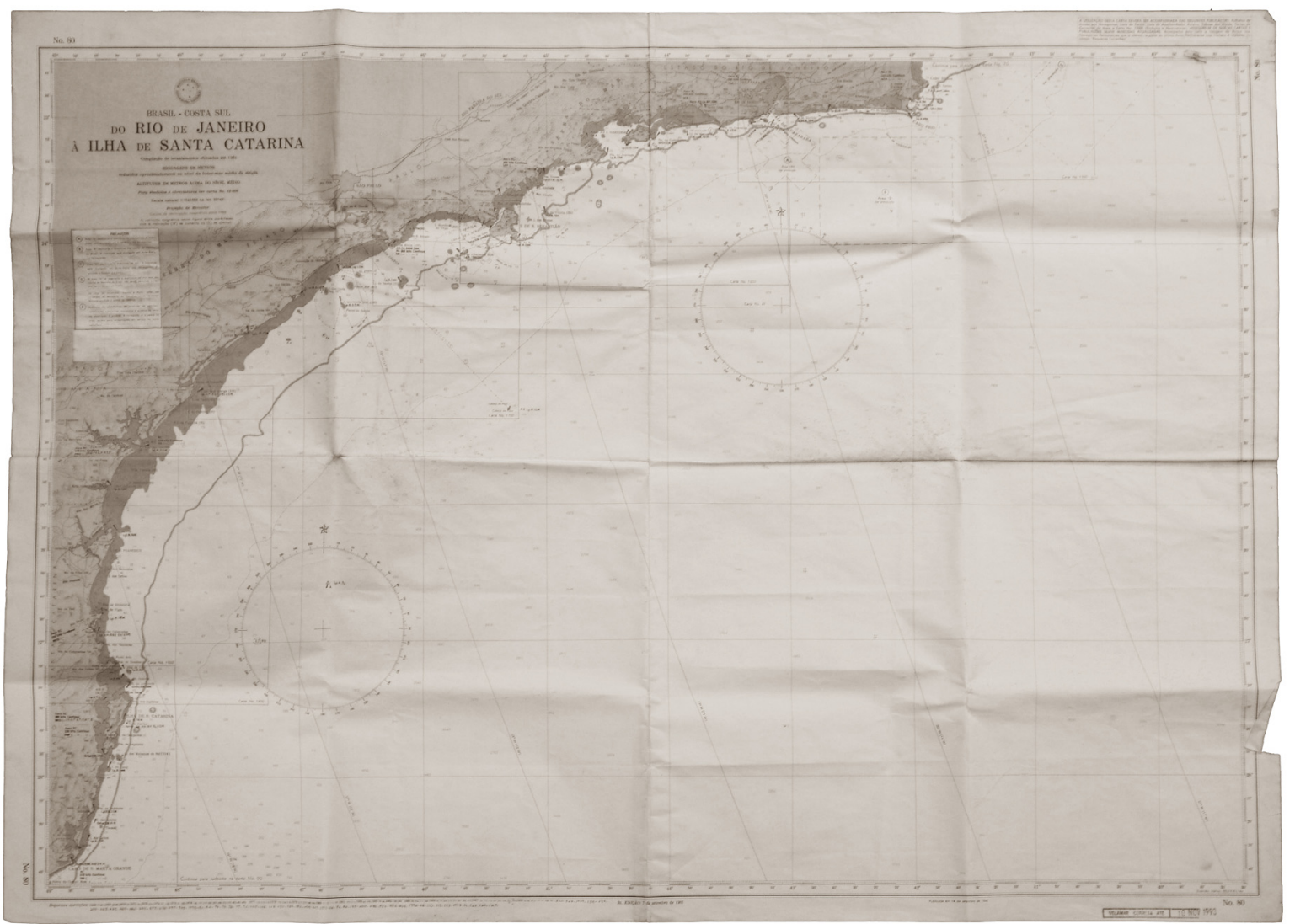

Carta Náutica do litoral de Santa Catarina ao Rio de Janeiro

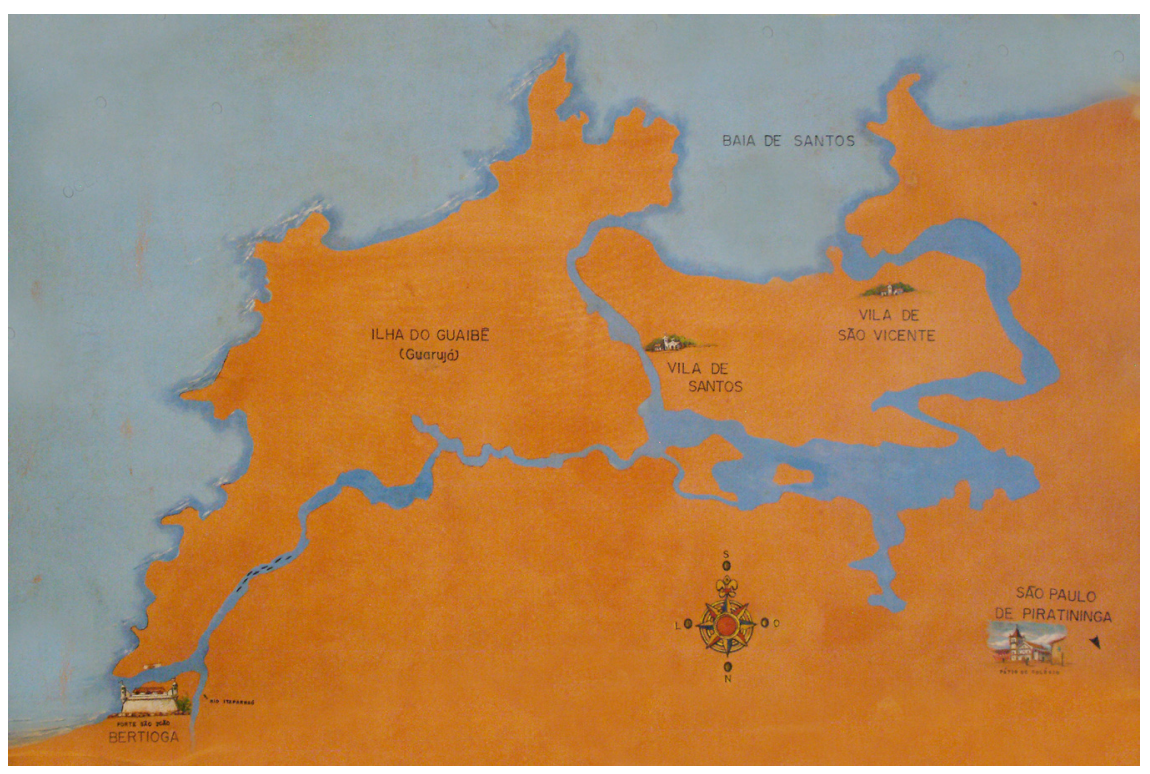

Itha do Guaibê 
(DIA ANOT) Viviam lá a tempos atrás, povos chamados Tupiniquins e Tupinambás que guerreavam entre si, viviam da pesca e da caça e plantavam mandioca da qual extraíam diferentes derivados. Estes povos eram selvagens, canibais, comiam uns aos outros como prova de conquista e poder. (Hans Staden, Duas Viagens ao Brasil - Editora da Universidade de São Paulo).

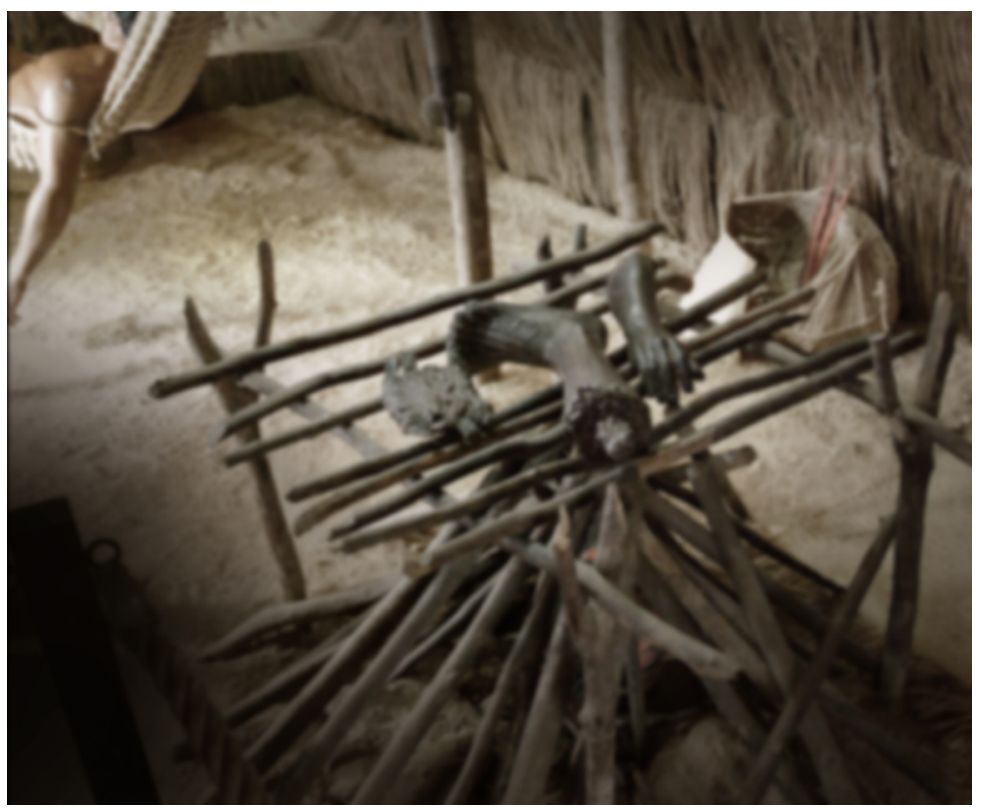

Tupiniquim descansa em palhoça após devorar Tupinambá 


\section{REFERÊNCIAS BIBLIOGRÁFICAS}

\section{Benjamin, Walter}

Pequena História da Fotografia. Editora Relógio d’Água, Lisboa, $1931 / 1992$

Kleine Geschichte der Fotografie. Suhrkkamp Leipzig, 1931 / 1996

Das Kunstwerk in Zeitalter Seiner Technischen Reproduzierbarkeit.

Suhrkkamp Leipzig, 1935 / 1996

\section{Buchloch, Bejamin H.D}

Das Archiv der Anomie. Ueber Gehardt Richter Atlas.

Bonn, Dumond, 1994

\section{Cabane, Pierre}

Marcel Duchamp: Engenheiro do Tempo Perdido.

São Paulo, Perspectiva, 1987

\section{Chiarelli Tadeu, Mendes Ricardo}

Fotografias no acervo do Museu de Arte Moderna de São Paulo.

São Paulo, Museu de Arte Moderna de São Paulo, 2002

\section{Friedel, Helmut}

Der Atlas 1962-1997 Gehardt Richter. Koeln, Oktagon Verlag, 1997

\section{Galassi, Peter}

Andreas Gursky. New York, The Museum of Modern Art New York, 2001

\section{Kossoy, Borris}

Realidades Ficções na Trama Fotográfica. Atelie Editorial,

Cotia, SP Brasil, 2002

Fotografia \& História. Atelie Editorial, Cotia, SP Brasil, 2003

\section{Lang, Fritz}

Metropolis (Filme 1927)

O Vampiro de Duesseldorf (Filme 1931)

\section{Lange, Susanne}

Bernd und Hilla Becher Haueser und Hallen. Frankfurt am Main,

Museum fuer Moderne Kunst, 1992 


\section{Lauter, Rolf}

Jeff Wall, Figures and Places. Frankfurt am Main,

Museum fuer Moderne Kunst. Frankfurt am Main, 2002

\section{Sampaio, Teodoro}

O tupi na Geografia Nacional, Editora Nacional, Brasilia, 1987

\section{Sander, August}

Antlitz der Zeit: 60 Aufnahmen deutscher Menschen des 20 Jahrhunderts / August Sander. Mit Einleitung von Alfred Doeblin Muenchen, Schimer-Moesel, 1990

\section{Staden, Hans}

Duas Viagens ao Brasil, trad. Guiomar de Carvalho Franco, ITAIAIA Editora, Belo Horizonte, 1974

\section{Stals, José Lebreiro}

Heute bis Jetzt / Zeitgenoessische Fotografie aus Duesseldorf.

Muenchen, Schimer-Moesel, 2002

\section{Turazzi, Maria Inez}

Marc Ferrez, Fotografias de um Artista llustrado.

Cosac \& Naify, São Paulo, 2000 